\title{
Metal Halide Perovskite Single Crystals: From Growth Process to Application
}

\author{
Shuigen Li ${ }^{1, *}$, Chen Zhang ${ }^{2}$, Jiao-Jiao Song ${ }^{2}$, Xiaohu Xie ${ }^{1}$, Jian-Qiao Meng ${ }^{2,3, * \mathbb{B}}$ and \\ Shunjian $X \mathbf{u}^{1, *}$ \\ 1 School of New Energy Science and Engineering, Xinyu University, Xinyu 338004, China; \\ xie19930723@163.com \\ 2 Hunan Key Laboratory for Super-Microstructure and Ultrafast Process, School of Physics and Electronics, \\ Central South University, Changsha 410083, China; zhangchen@csu.edu.cn (C.Z.); \\ 162211012@csu.edu.cn (J.-J.S.) \\ 3 Synergetic Innovation Center for Quantum Effects and Applications (SICQEA), Hunan Normal University, \\ Changsha 410081, China \\ * Correspondence: sgli76@163.com (S.L.); jqmeng@csu.edu.cn (J.-Q.M.); xushunjian@126.com (S.X.)
}

Received: 21 April 2018; Accepted: 9 May 2018; Published: 17 May 2018

check for updates

\begin{abstract}
As a strong competitor in the field of optoelectronic applications, organic-inorganic metal hybrid perovskites have been paid much attention because of their superior characteristics, which include broad absorption from visible to near-infrared region, tunable optical and electronic properties, high charge mobility, long exciton diffusion length and carrier recombination lifetime, etc. It is noted that perovskite single crystals show remarkably low trap-state densities and long carrier diffusion lengths, which are even comparable with the best photovoltaic-quality silicon, and thus are expected to provide better optoelectronic performance. This paper reviews the recent development of crystal growth in single-, mixed-organic-cation and fully inorganic halide perovskite single crystals, in particular the solution approach. Furthermore, the application of metal hybrid perovskite single crystals and future perspectives are also highlighted.
\end{abstract}

Keywords: perovskite single crystals; growth process; application; solar cell; photodetector

\section{Introduction}

Recently, organic-inorganic metal hybrid perovskites have shown great applied potential because of their impressive optical and electrical properties [1-5], which can be represented by the structure $\mathrm{ABX}_{3}$, where $\mathrm{A}$ is $\mathrm{CH}_{3} \mathrm{NH}_{3}{ }^{+}, \mathrm{CH}\left(\mathrm{NH}_{2}\right)_{2}{ }^{+}$or $\mathrm{Cs}^{+}, \mathrm{B}$ is $\mathrm{Pb}^{2+}$ or $\mathrm{Sn}^{2+}$, and $\mathrm{X}$ is $\mathrm{I}^{-}, \mathrm{Br}^{-}$or $\mathrm{Cl}^{-}$[6-27]. The ideal $\mathrm{ABX}_{3}$ structure is cubic symmetry, where $\mathrm{A}$ and $\mathrm{B}$ ions are located at the eight corners and center of a cubic unit, respectively. The symmetry of $\mathrm{ABX}_{3}$ structures is based on the atomic species of the $A$ and $B$ sites. In a typical perovskite crystal structure, the $A, B$, and $X$ ionic radii, e.g., $R_{A}, R_{B}$, and $R_{X}$, should correspond to a specific geometric relationship, known as the Tolerance factor [28-30]: $t=\left(\mathrm{R}_{\mathrm{A}}+\mathrm{R}_{\mathrm{X}}\right) / \sqrt{2}\left(\mathrm{R}_{\mathrm{B}}+\mathrm{R}_{\mathrm{X}}\right)$. The ideal value of $t$ should be 1 for cubic structures; otherwise, the structure tends to be distorted, or even destroyed [28,30,31]. For lead hybrid perovskite, the large organic cation at the A position, e.g., methylammonium $\left(\mathrm{MA}^{+}\right)$or formamidinium $\left(\mathrm{FA}^{+}\right)$, is able to match the large radius of the $\mathrm{Pb}^{2+}$ ion at the $\mathrm{B}$ position and meet the tolerance factor $t$, while the halogen anions or their mixtures occupy the $C$ positions, resulting in the formation of a 3D perovskite structure [32]. These perovskite-based materials, when used in the photovoltaic field, can provide remarkable properties, such as broad absorption from the visible to the near-infrared region, tunable optical and electronic properties [15,33-36], high charge mobility, and long exciton diffusion length and carrier recombination lifetime [32,37-48]. Within a few years, they have revolutionized the 
photovoltaic field; an efficiency of $22.1 \%$ from solution-processable perovskite-based solar cells has been reported [49]. In addition, lead hybrid perovskites have also been used in some other fields, such as laser [50], photodetector [51], light-emitting-diodes [52], thermoelectricity [53], and catalysis [54], demonstrating their potential application prospects.

Until now, many intensive investigations have been based on polycrystalline thin films, one of the existing forms of perovskite, and most of the results have been focused on the perovskite polycrystalline film. With in-depth research, single crystals-another form of perovskite-have been found with low defect density. The carrier diffusion length of perovskite is sensitive to defects. When expanding the grain size, the carrier diffusion length of polycrystalline forms can increase to up to $1 \mu \mathrm{m}$, while large single crystals are able to provide even longer carrier diffusion lengths. Dong et al. prepared millimeter-sized $\mathrm{MAPbI}_{3}$ single crystals via a low-temperature solution approach, in which a carrier diffusion length of over $175 \mu \mathrm{m}$ was obtained under 1 sun illumination, and a longer carrier diffusion length exceeding $3 \mathrm{~mm}$ could be produced under a weaker illumination with $0.003 \%$ sun illumination [55]. Shi et al. reported low trap-state density of states with an order of $10^{9}-10^{10} \mathrm{~cm}^{-3}$ and carrier diffusion length $>10 \mathrm{~mm}$ in $\mathrm{MAPbX}_{3}$ single crystals [40]. The longer carrier diffusion length in single crystals with low trap-state density derives from their better extraction and transport of photogenerated charge carriers, resulting in a performance boost for optoelectronic devices. These meaningful findings will contribute to the development of perovskite-based materials, and will be extremely beneficial to further fundamentally investigate the intrinsic properties of perovskites single crystals. To date, single-organic-cation, mixed-organic-cation, and all-inorganic kinds of metal halide perovskite single crystals have been demonstrated. In this review, we will summarize the advances in the growth and application of the above perovskite single crystals.

\section{Growth of Organic-Inorganic Hybrid Halide Perovskite Single Crystals}

Since organic-inorganic metal hybrid perovskite solar cells (PSCs) were studied for the first time [5], they have attracted particular attention due to their extraordinary performance. Since then, in-depth study on perovskite-based materials and devices has been carried out, and a series of research results have been obtained. Meanwhile, perovskite single crystals, which were reported about forty years ago $[40,56,57]$, are studied again.

\subsection{Growth of Single-Organic-Cation Halide Perouskite Single Crystals}

Solution temperature lowering (STL) is a traditional single crystal growth process. In 1987, Poglitsch et al. gained MA-based perovskite single crystals via a temperature-lowering method [58] in which they heated the mixed solution to $100^{\circ} \mathrm{C}$, and perovskite single crystals were grown by cooling the solution to room temperature. In general, minimizing the number of nuclei is crucial to growing large single crystals. As an improved technology, seed-assisted growth is often adopted for the purpose of growing large-sized and high-quality single crystals, i.e., small crystals are firstly put into a single crystal precursor, followed the temperature-lowering process. Using a slow cooling rate of $0.1-0.2^{\circ} \mathrm{C} / \mathrm{h}$, Su et al. obtained large $\mathrm{MAPbI}_{3}$ single crystals with sizes of up to $1 \mathrm{~cm}$ [59] by a process in which small crystals were firstly obtained by spontaneous nucleation (Figure 1a), then high-quality as-grown crystals were selected as seeds and dropped back into the mother liquid to grow large single crystals (Figure $1 \mathrm{~b}$ ). Similarly, $\mathrm{MAPbBr}_{3}$ single crystals with perfect cubic structure were formed. Dang et al. grew tetragonal $\mathrm{MAPbI}_{3}$ bulk single crystals with dimensions of $10 \mathrm{~mm} \times 10 \mathrm{~mm} \times 8 \mathrm{~mm}$ by a seed-assisted growth method [60] in which the seeded crystal was fixed in the middle of the solution. The solution was saturated gradually with a decrease of temperature from $65^{\circ} \mathrm{C}$ to $40{ }^{\circ} \mathrm{C}$, resulting in the formation of high-quality single crystals over the following few days.

Huang's [36] group grew large bulk $\mathrm{MAPbI}_{3}$ single crystals with a size of $10 \mathrm{~mm} \times 3.3 \mathrm{~mm}$ via a temperature-lowering method, as presented in Figure 1c, in which the seed crystal was fixed in the top half of the solution. Importantly, they dissolved the seed crystals in the bottom of the precursor solution, and the super saturation of the top solution was readily induced because of the temperature 
gradient between the top and bottom, leading to fast-growing of single crystals with a rate of about $2 \mathrm{~mm}$ per day.
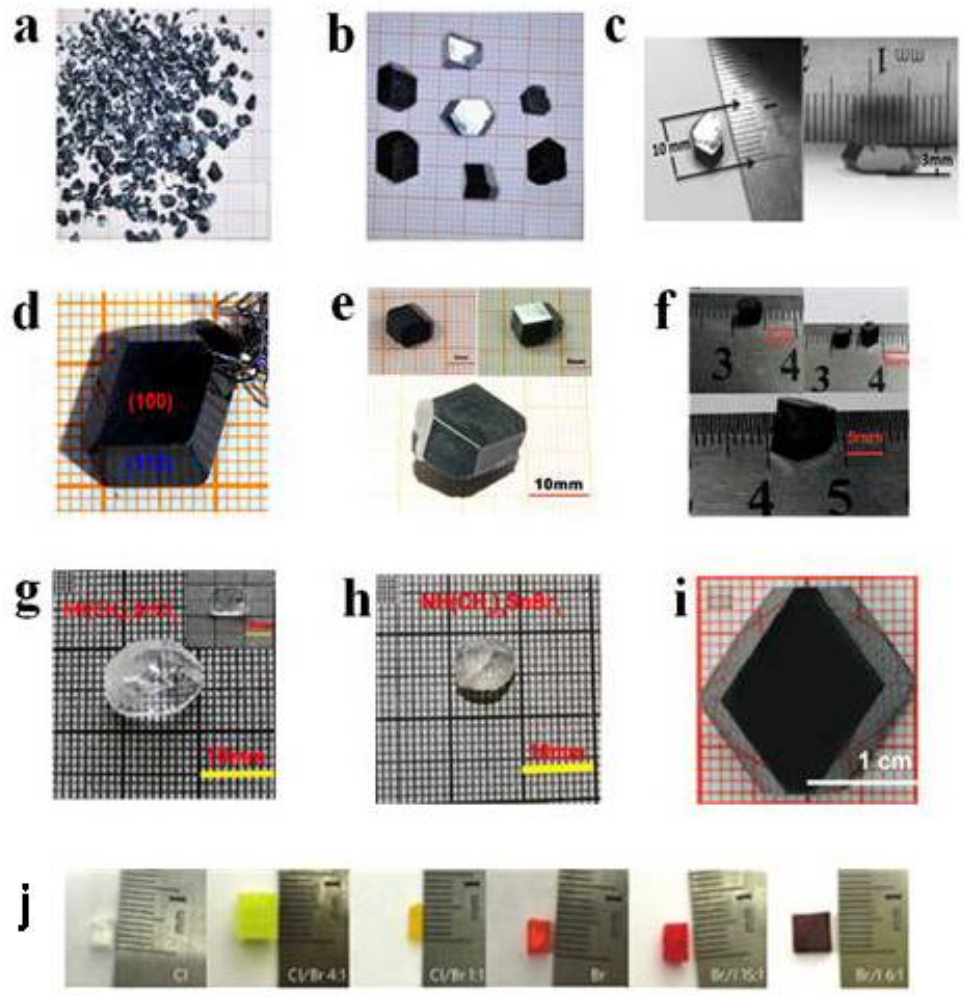

Figure 1. (a) $\mathrm{MAPbI}_{3}$ crystal grains obtained by spontaneous nucleation; and (b) grown large $\mathrm{MAPbI}_{3}$ crystals obtained using seeds. Reprinted with permission from [59], Copyright 2015, Elsevier B.V.; (c) large bulk $\mathrm{MAPbI}_{3}$ single crystals with sizes of $10 \mathrm{~mm} \times 3.3 \mathrm{~mm}$. Reprinted with permission from [36], Copyright 2015, American Association for the Advancement of Science; (d) $\mathrm{MAPbI}_{3}$ single crystal grown using the BSSG method. Reprinted with permission from [61], Copyright 2015, Springer; (e) $\mathrm{CH}_{3} \mathrm{NH}_{3} \mathrm{SnI}_{3}$ and (f) $\mathrm{CH}\left(\mathrm{NH}_{2}\right)_{2} \mathrm{SnI}_{3}$ single crystals grown via the TSSG method. Reprinted with permission from [62], Copyright 2016, Wiley; (g) $\mathrm{NH}\left(\mathrm{CH}_{3}\right)_{3} \mathrm{SnCl}_{3}$ and (h) $\mathrm{NH}\left(\mathrm{CH}_{3}\right)_{3} \mathrm{SnBr}_{3}$ single crystals prepared via the BSSG method. Reprinted with permission from [63], Copyright 2016, American Chemical Society; (i) $\mathrm{MAPbI}_{3}(\mathrm{Cl})$ bulk single crystals grown by rapid solution temperature-lowering method. Reprinted with permission from [64], Copyright 2016, American Chemical Society; (j) mixed-halide perovskite single crystals with different halide compositions. Reprinted with permission from [65], Copyright 2015, Springer.

Using the bottom-seeded solution growth (BSSG) method, Lian et al. [61] prepared centimeter-sized bulk $\mathrm{MAPbI}_{3}$ single crystals. To eliminate the negative effect of multiple nuclei, a seed crystal was fixed by platinum wire to segregate the seed crystal from the bottom of the flask, and the desired single crystal, $12 \mathrm{~mm} \times 12 \mathrm{~mm} \times 7 \mathrm{~mm}$ in size, was obtained by lowering the temperature of the growth solution from $373 \mathrm{~K}$ to $330 \mathrm{~K}$, as shown in Figure $1 \mathrm{~d}$.

Tin-based perovskite single crystals have also been harvested by the temperature-lowering method. Tao and co-worker reported bulk cubic $\mathrm{CH}_{3} \mathrm{NH}_{3} \mathrm{SnI}_{3}$ and $\mathrm{CH}\left(\mathrm{NH}_{2}\right)_{2} \mathrm{SnI}_{3}$ single crystals grown via a top-seeded solution growth (TSSG) method (Figure 1e,f) [62]. Similarly, $\mathrm{NH}\left(\mathrm{CH}_{3}\right)_{3} \mathrm{SnX}_{3}$ $(\mathrm{X}=\mathrm{Cl}, \mathrm{Br})$ single crystals were prepared via the TSSG method [63], as shown in Figure 1g,h.

Lian et al. reported a rapid solution temperature-lowering method to prepare Mixed-halide perovskite single crystals based on the addition of chlorine [64]. With the addition of chlorine, the surface free energy and the edge free energy were changed. The resulting edge free energy is expressed by: $\rho_{\text {Chlorine }}=\rho-k_{B} T \ln C_{\text {Chlorine, }}$ given that the edge free energy $\rho_{\text {Chlorine }}$ decreases with $C_{\text {Chlorine, }}$, the 
growth rate of $\mathrm{CH}_{3} \mathrm{NH}_{3} \mathrm{PbI}_{3}(\mathrm{Cl})$ crystal face will increase. They harvested large $\mathrm{CH}_{3} \mathrm{NH}_{3} \mathrm{PbI}_{3}(\mathrm{Cl})$ with sizes of $20 \mathrm{~mm} \times 18 \mathrm{~mm} \times 6 \mathrm{~mm}$ within only 5 days (Figure 1i) that possessed excellent properties, i.e., a high carrier mobility of $167 \pm 35 \mathrm{~cm}^{2} \cdot \mathrm{V}^{-1} \cdot \mathrm{s}^{-1}$, a low trap-state density of $7.6 \times 10^{8} \mathrm{~cm}^{-3}$, and a transient carrier lifetime as long as $449 \pm 76 \mu \mathrm{s}$. Mixed-halide perovskite single crystals can also be grown via solw temperature-lowering method [65]. At $100^{\circ} \mathrm{C}$, a super-saturated aqueous solution, including single or mixed haloid acid of different halide ratios, mixing methylamine and lead (II) acetate, was prepared. By gradually lowering the precursor solution temperature, a series of perovskite single crystals, depending on the different halide ratios, could readily be formed, as presented in Figure $1 \mathrm{j}$. As is shown, for both $\mathrm{MAPbBr}_{3-x} \mathrm{Cl}_{x}$ and $\mathrm{MAPbI}_{3-x} \mathrm{Br}_{x}$ single crystals, the color varies with the different halide ratios of $\mathrm{Br} /(\mathrm{Cl}+\mathrm{Br})$ and $\mathrm{I} /(\mathrm{I}+\mathrm{Br})$.

The STL method provides a simple and effective approach for the growth of $\mathrm{MAPbX}_{3}$ and $\mathrm{FAPbX}_{3}$, in which the crystals are formed with the decrease in the temperature of the precursor solution. However, the drawback of its being highly time-consuming (typically more than two weeks to gain one-centimeter-sized crystals $[61,62]$ ) limits its extensive use. On the other hand, the solute solubility in solvents decreases with increasing temperature for a few materials [66], i.e., inverse temperature solubility, which is also present for organic-inorganic metal hybrid perovskites. For example, $\mathrm{MAPbI}_{3}$, $\mathrm{MAPbBr}_{3}$ and $\mathrm{MAPbCl}_{3}$ show inverse temperature solubility in certain solvents-gamma-butyrolactone (GBL), N,N-dimethylformamide (DMF), and dimethylsulfoxide (DMSO), respectively. Based on the above characteristics, inverse temperature crystallization (ITC) was first introduced to grow $\mathrm{MAPbI}_{3}$ single crystals. During the ITC, the precursor was dissolved in GBL and the temperature was increased until single crystals formed at about $190{ }^{\circ} \mathrm{C}$ [67]. At the same time, Saidaminov et al. designed inverse temperature crystallization (ITC) for $\mathrm{MAPbX}_{3}$ perovskites due to their inverse temperature solubility behavior in some solvents [68]. They grew size- and shape-controlled high-quality $\mathrm{MAPbI}_{3}$ and $\mathrm{MAPbBr}_{3}$ single crystals within several hours (Figure 2a).

To grow large single crystals and understand their growth mechanism, Liu's group developed the seed-repeated method and harvested the largest $\mathrm{MAPbI}_{3}$ single crystal, with a size of $71 \mathrm{~mm} \times 54 \mathrm{~mm} \times 39 \mathrm{~mm}$, as well as inch-sized $\mathrm{MAPbBr}_{3}$ and $\mathrm{MAPbCl}_{3}$ crystals (Figure 2g) [69]. In the process of crystal growth, small perovskite particulates were harvested as seed crystals to keep in precursor solution at $100{ }^{\circ} \mathrm{C}$ for $24 \mathrm{~h}$. A seed crystal was placed in precursor solution to keep at $100{ }^{\circ} \mathrm{C}$ for $48 \mathrm{~h}$, resulting in the formation of a larger crystal. By repeating the above process, the final large crystals would be produced. Figure $2 j$ shows the absorbance spectra of $\mathrm{MAPbX}_{3}$ $(\mathrm{X}=\mathrm{Cl}, \mathrm{Br}, \mathrm{I})$ perovskites. A clear band edge without excitonic signature or absorption is shown, indicating high-quality single crystals with low defect concentration. Furthermore, all of the PL spectra of $\mathrm{MAPbCl}_{3}, \mathrm{MAPbBr}_{3}$, and $\mathrm{MAPbI}_{3}$ perovskites exhibited narrow PL peaks at $\approx 402, \approx 537$, and $\approx 784 \mathrm{~nm}$, respectively (Figure $2 \mathrm{k}$ ), and the PL peak values were smaller than the corresponding absorption onsets $(431,574$, and $836 \mathrm{~nm})$, indicating their advantageous application in solar cells. The X-ray Diffraction (XRD) measurement displayed that the (200) diffraction peak of $\mathrm{MAPbI}_{3}$ single crystal showed a FWHM of $0.3718^{\circ}$, which indicated that the single crystal held a respectable crystalline quality. Electric characterization showed that the electron trap was $1.1 \times 10^{11} \mathrm{~cm}^{-3}$ for $\mathrm{MAPbBr}_{3}$ and $4.8 \times 10^{10} \mathrm{~cm}^{-3}$ for $\mathrm{MAPbI}_{3}$. The hole trap densities for $\mathrm{MAPbBr}_{3}$ and $\mathrm{MAPbI}_{3}$ were determined to be $2.6 \times 10^{10} \mathrm{~cm}^{-3}$ and $1.8 \times 10^{9} \mathrm{~cm}^{-3}$, respectively. Furthermore, the crystalline $\mathrm{MAPbX}_{3}(\mathrm{X}=\mathrm{I}, \mathrm{Cl}, \mathrm{Br})$ gave a high carrier mobility of $34 \mathrm{~cm}^{2} \cdot \mathrm{V}^{-1} \cdot \mathrm{s}^{-1}, 179 \mathrm{~cm}^{2} \cdot \mathrm{V}^{-1} \cdot \mathrm{s}^{-1}$ and $4.36 \mathrm{~cm}^{2} \cdot \mathrm{V}^{-1} \cdot \mathrm{s}^{-1}$. It is expected that such wafer-sized single-crystalline $\mathrm{MAPbX}_{3}(\mathrm{X}=\mathrm{I}, \mathrm{Cl}, \mathrm{Br})$ with superior properties in terms of defect state and carrier density are promising materials for high-performance optoelectronic devices.

The ITC method is a highly effective approach for growing metal hybrid halide perovskite crystals that possesses a much faster growth rate than that of the typical STL method and has been used extensively to grow single or mixed halide perovskite crystalline materials [67,70-74]. Additionally, the ITC method meets the requirements of $\mathrm{FAPbX}_{3}$ single crystals. Bakr's group reported the retrograde solubility of FA-based perovskites and grew high-quality crack-free $\mathrm{FAPbI}_{3}$ and $\mathrm{FAPbBr}_{3}$ single crystals (Figure 2h,i) [75]. By improving the onset of crystallization temperature, they obtained grain 
boundary-free $\mathrm{FAPbI}_{3}$ crystals within $3 \mathrm{~h}$. Yang's group obtained 5-mm-sized $\mathrm{FAPbI}_{3}$ single crystals for the first time via a modified ITC method [74]. They first grew the $\mathrm{FAPbI}_{3}$ seed crystal via a cooling solution method, followed by growing larger single crystals by placing the small seed crystals into the ITC precursor and keeping at $100^{\circ} \mathrm{C}$.

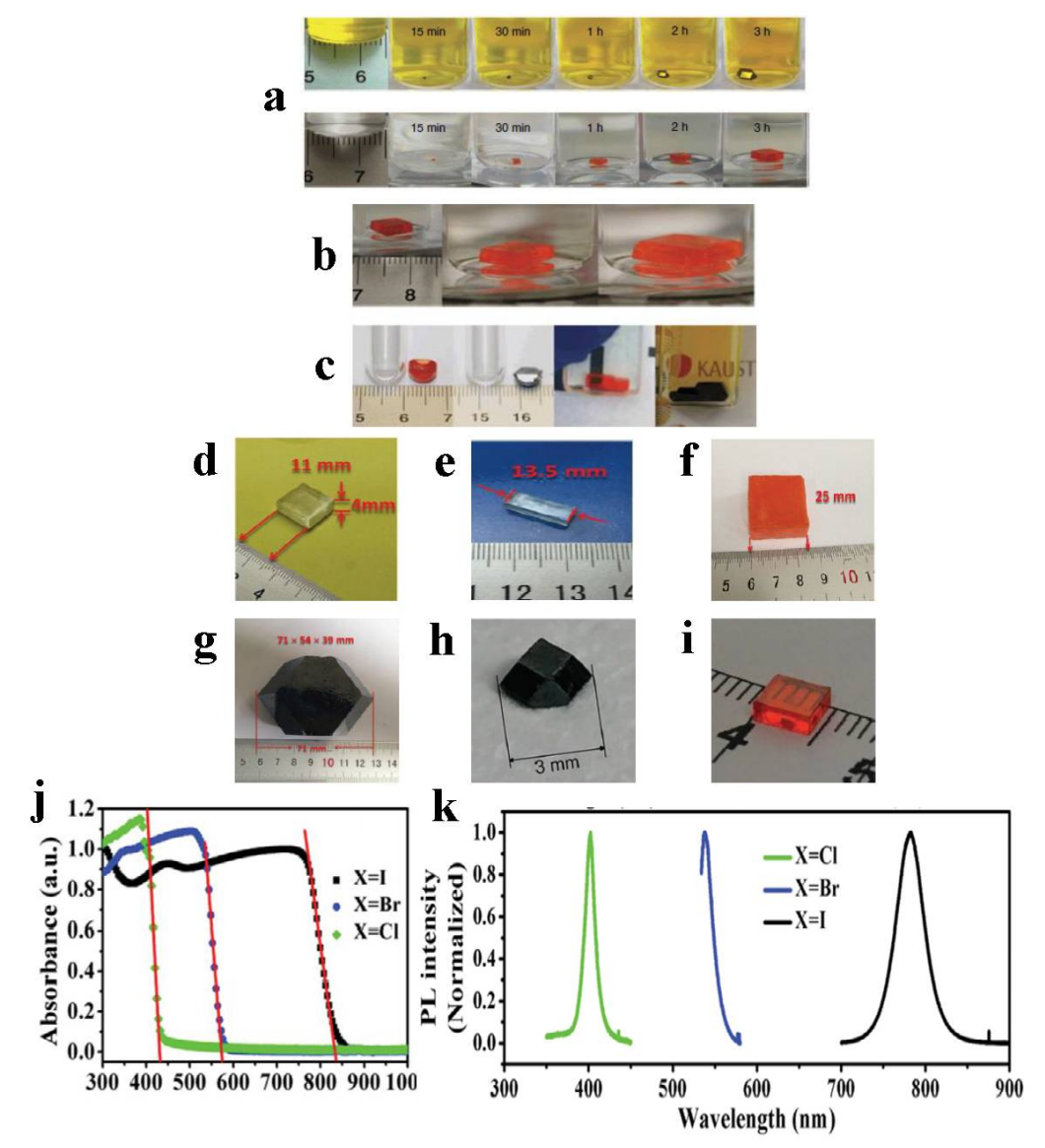

Figure 2. (a) $\mathrm{MAPbI}_{3}$ and $\mathrm{MAPbBr}_{3}$ single crystal growth at different time intervals, (b) continuous growth of $\mathrm{MAPbBr}_{3}$, and (c) crystal shape control of $\mathrm{MAPbBr}_{3}$ (red) and $\mathrm{MAPbI}_{3}$ (black). Reprinted with permission from [68], Copyright 2015, Springer; Photographs taken from the as-grown $\mathrm{MAPbX}_{3}$ crystals: (d,e) $\mathrm{MAPbCl}_{3}$ (f) $\mathrm{MAPbBr}_{3}$ (g) $\mathrm{MAPbI}_{3}$. Reprinted with permission from [69], Copyright 2015, Wiley; (h) $\mathrm{FAPbI}_{3}$ (black) and (i) $\mathrm{FAPbBr}_{3}$ (red) single crystal grown by the ITC method. Reprinted with permission from [75], Copyright 2016, Royal Society of Chemistry; UV-vis-NIR absorption spectrum and photoluminescence (PL) properties of $\mathrm{CH}_{3} \mathrm{NH}_{3} \mathrm{PbX}_{3}(\mathrm{X}=\mathrm{Cl}, \mathrm{Br}, \mathrm{I})$ : (j) absorption spectrum and (k) photoluminescence spectrum. Reprinted with permission from [69], Copyright 2015, Wiley.

In addition to the above growth method based upon temperature, the antisolvent vapor-assisted crystallization (AVC) method, a temperature-independent process, was also developed [40]. In AVC, a proper anti-solvent slowly diffuses into the crystal precursor solution, resulting in formation of sizable $\mathrm{MAPbX}_{3}$. Using the AVC method, Bakr's group [40] gained high-quality $\mathrm{MAPbI}_{3}$ and $\mathrm{MAPbBr}_{3}$ single crystals, and implemented a solvent with high solubility for $\mathrm{MAX}$ and $\mathrm{PbX}_{2}$, i.e., $\mathrm{N}, \mathrm{N}$-Dimethylformamide (DMF) or $\gamma$-butyrolactone (GBA). Dichloromethane (DCM) acted as the antisolvent to avoid the formation of hydrogen bonds due to its poor solubility for both $\mathrm{PbX}_{2}$ and MAX, thus minimizing asymmetric interactions with the ions during their assembly into crystal form. This approach created the conditions for the coprecipitation of the ionic building blocks of perovskite. When DCM diffused into DMF or GBA at a slow and controlled rate (Figure 3a), millimeter-sized $\mathrm{MAPbBr}_{3}$ and $\mathrm{MAPbI}_{3}$ single crystals were grown. As shown in Figure 3a, to obtain $\mathrm{MAPbBr}_{3}$ single crystals, $\mathrm{PbBr}_{2} / \mathrm{MABr}$ molar ratio of 1:1 was chosen and dissolved in DMF to form the precursor with 
$\mathrm{PbI}_{2}$ of $0.2 \mathrm{~mol} \cdot \mathrm{L}^{-1}$. For $\mathrm{MAPbI}_{3}$ single crystals, a precursor with $\mathrm{PbI}_{2} / \mathrm{MAI}$ molar ratio of 1:3 was dissolved in $\mathrm{GBA}$, and $\mathrm{PbI}_{2}$ of $0.5 \mathrm{~mol} \cdot \mathrm{L}^{-1}$ was prepared. In this case, high-quality $\mathrm{MAPbX}_{3}$ single crystals were obtained, with super-excellent performance. The absorbance of $\mathrm{MAPbX}_{3}\left(\mathrm{X}=\mathrm{Br}^{-}\right.$and I- $)$ (Figure 3e) exhibited a clear band edge cutoff without excitonic signature that showed a minimal number of in-gap defect states. This confirmed a carrier (holes) concentration of $5 \times 10^{9}-5 \times 10^{10} \mathrm{~cm}^{-3}$. The time-dependent $\mathrm{PL}$ signals of $\mathrm{MAPbI}_{3}$ and $\mathrm{MAPbBr}_{3}$ single crystals were obtained in order to quantify the carrier dynamics (Figure 3f), and showed a superposition of surface components (fast) $\tau \approx 41$ ns and bulk components (slow) $\tau \approx 357$ ns for MAPbBr 3 , and fast $\tau \approx 22$ ns and slow $\tau \approx 1032 \mathrm{~ns}$ for $\mathrm{MAPbI}_{3}$. For MAPbBr 3 single crystals, the carrier lifetime $\tau$ was also estimated by transient absorption (TA). It was shown that the fast component amounts to only $3.6 \%$ of the total TA signal in $\mathrm{MAPbBr}_{3}$, and to $7 \%$ and $12 \%$ of the total PL signal in $\mathrm{MAPbI}_{3}$ and $\mathrm{MAPbBr}_{3}$, respectively. As an alternative antisolvent, toluene can also effectively induce formation of $\mathrm{MAPbBr}_{3}$ single crystals (Figure $3 \mathrm{~b}$ ) with low surface recombination velocity $\left(\sim(3.4 \pm 0.1) \times 10^{3} \mathrm{~cm} \cdot \mathrm{s}^{-1}\right)$ [76] through a process in which the crystal precursor is derived from dissolution of $\mathrm{PbBr}_{2}$ and $\mathrm{MABr}(1 / 1$ by molar, $0.1 \mathrm{~mol} \cdot \mathrm{L}^{-1}$ ) in DMF. In another study, diethyl ether was reported as the antisolvent [77], in which $\mathrm{HI}$ served as the good solvent instead of organic solvents. Where $\mathrm{PbI}_{2}$ was firstly dissolved in $\mathrm{HI}$ solution upon heating to $120^{\circ} \mathrm{C}$, and formed a hot bright yellow solution; to the hot solution was added MAI, which dissolved immediately, leading to the formation of the crystal precursor. $X$-ray Diffraction (XRD) analysis revealed that an intermediate product of $\mathrm{H}_{x} \mathrm{PbI}_{2+x} \cdot x \mathrm{H}_{2} \mathrm{O}$ was created because of the coordination between $\mathrm{HI}$ and $\mathrm{PbI}_{2}$. With inflow of diethyl ether into the precursor, $\mathrm{MAPbI}_{3}$ single crystals emerged developmentally. It's worth mentioning that the growth mechanism of halide perovskite single crystals was studied. Recently, Chen et al. reported the growth mechanism of $\mathrm{MAPbBr}_{3}$ single crystal, which was synthesized by the antisolvent method [78]. The assembly model is shown in Figure 3c. $\mathrm{CH}_{3} \mathrm{NH}_{3} \mathrm{Br} \cdot \mathrm{PbBr}_{2}$. $\mathrm{DMF}$ adduct complex was first formed in the precursor solution, and crystallization occurred when the solution was supersaturated. The $\mathrm{MAPbBr}_{3}$ molecule in the saturated solution condensed into numerous small nuclei with the coalescence of the nuclei into bigger particles. The perovskite particles were gradually self-assembled into a hollow structure. The crystals were twisted, and their faces were peculiarly inclined toward each other. Subsequently, $\mathrm{MAPbBr}_{3}$ crystals exhibited a layered stacked structure, and continued to grow until the final single crystal was formed. $\mathrm{Li}$ and co-workers investigated the crystallization of $\mathrm{MAPbI}_{3-x} \mathrm{Br}_{x}$ by adjusting the molar ratio of I/Br in precursor solution [79]. It was found that the crystallization and perovskite morphology were heavily affected by the composition of precursor solutions (Figure 3d). It was reported that $\mathrm{Br}$ has a smaller ionic radius and lower solubility in organic solvents because of the stronger bond strength [80]. As a comparison with $\mathrm{PbBr}_{2}, \mathrm{PbI}_{2}$ has a stronger electron-accepting ability and Lewis acidity [81]. Therefore, it was more likely to form needle crystals of $\mathrm{MAPbI}_{3-x} \mathrm{Br}_{x}$. DMF with high iodine concentration, which might lead to morphology evolution as the molar ratio of I/ Br.

Bulk perovskite single crystals can show advanced properties, such as higher carrier mobility, longer carrier lifetime and diffusion length. However, bulk single crystals may cause degradation of device performance, because a thick active layer will increase the charge recombination. In this case, it is desirable to achieve the fabrication of perovskite single-crystal thin films, and thus to enhance the performance of the device. Bakr's group grew $\mathrm{MAPbBr}_{3}$ monocrystalline film successfully via a cavitation-triggered asymmetrical (CTAC) strategy [82] in which a very short ultrasonic pulse was introduced to a low supersaturation level solution with antisolvent vapor diffusion; perovskite monocrystalline films were able to grow within several hours under the ultrasonic pulse. These obtained films were free of grain boundaries and were homogeneous, with the films having thicknesses ranging from one up to several tens of micrometers, and lateral dimensions varying from hundreds of microns to three millimeters, as shown in Figure 4a. 
$\mathbf{a}$

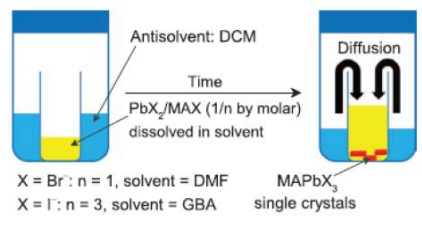

c

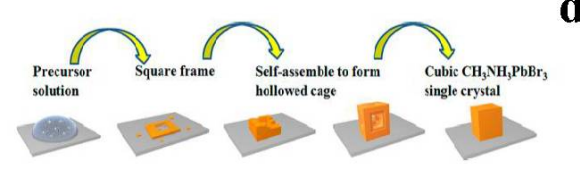

b

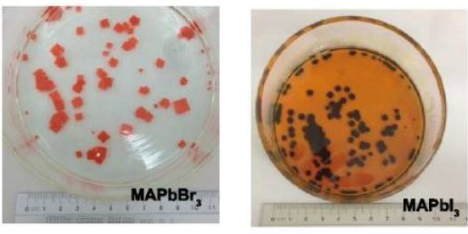

d

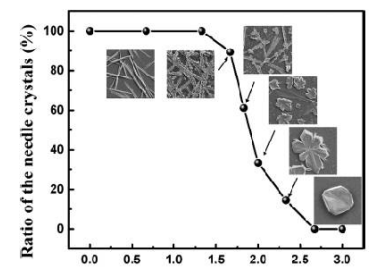

$\mathrm{MAPbl}_{3}$

$\mathbf{e}$
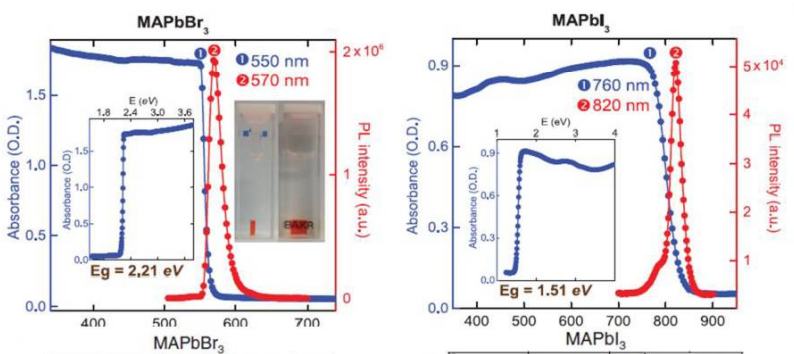

f
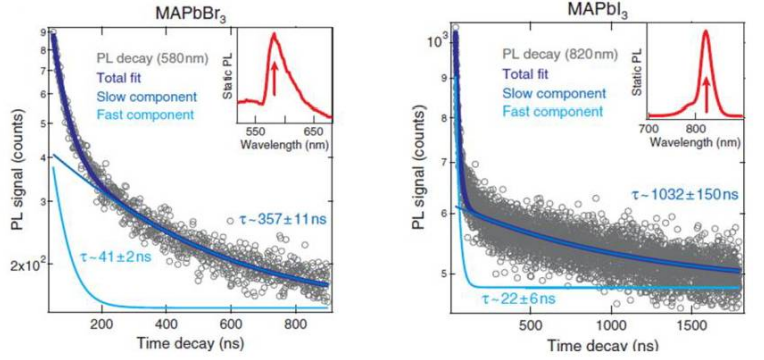

Figure 3. (a) Chemotic diagram of crystallization process of AVC method. Reprinted with permission from [40], Copyright 2015, AAAS; (b) $\mathrm{MAPbBr}_{3}$ (red) and $\mathrm{MAPbI}_{3}$ (black) single crystals grown by AVC. Reprinted with permission from [76], Copyright 2015, American Association for the Advancement of Science; (c) Schematic illustration of $\mathrm{MAPbBr}_{3}$ single crystal crystallization. Reprinted with permission from [78], Copyright 2018, American Chemical Society; (d) Dependence of ratio of the needle crystals on the bromine concentration of $x$. Reprinted with permission from [79], Copyright 2018, American Chemical Society; (e) Steady-state absorbance and photoluminescence and (f) PL time decay trace on $\mathrm{MAPbBr}_{3}$ and $\mathrm{MAPbI}_{3}$ crystal. Reprinted with permission from [40], Copyright 2015, AAAS.

To obtain $\mathrm{MAPbI}_{3}$ perovskite single-crystalline wafer, Liu's group designed an ultrathin geometry-defined dynamic-flow reaction system (Figure 4c) to obtain single crystals with different thicknesses and shapes (Figure $4 \mathrm{~d}-\mathrm{m}$ ) [83]. It was shown that the two glass slides of the reaction system were separated and aligned in parallel by two spacers, leading to the single-crystalline wafer thickness and shape being defined by the spacers and slit channel design. Using the thickness-controllable reaction system, wafer as thin as about $150 \mu \mathrm{m}$ with high crystallinity and a low trap state density of $6 \times 10^{8} \mathrm{~cm}^{-3}$ was prepared. 

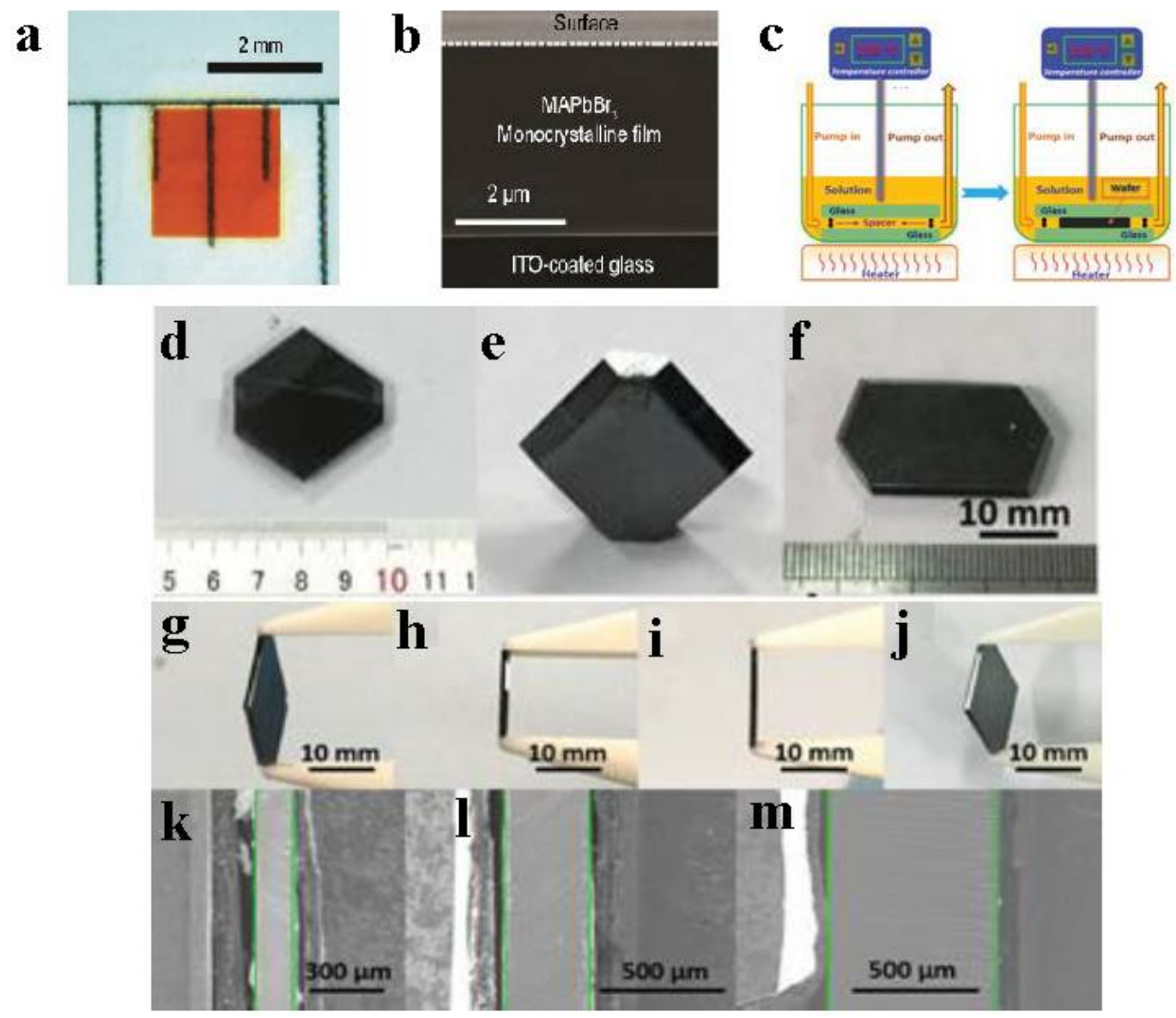

Figure 4. (a) Optical image and (b) cross-section $\mathrm{SEM}$ image of $\mathrm{MAPbBr}_{3}$ monocrystalline film. Reprinted with permission from [82], Copyright 2016, Wiley; (c) Schematic illustration for the ultrathin single crystal wafer preparation, $(\mathbf{d}-\mathbf{j})$ Photos of the single crystal wafers with different thicknesses and shapes, (k-m) Cross-sectional view of single crystal perovskite wafers showing different thicknesses. Reprinted with permission from [83], Copyright 2016, Wiley.

Chen et al. reported the controllable fabrication of air-stable, sub-millimeter-size perovskite single-crystalline thin films (SCTFs) [84]. For the preparation process, two flat substrates were clipped together and vertically immersed in perovskite precursor (Figure 5a), the thickness of the solution film could be easily tuned using clipping force, and the resulting SCTF thickness could be adjusted with an aspect ratio of up to $10^{5}$ from nano- to micrometers (Figure $5 \mathrm{~b}$ ). The prepared SCTFs exhibited outstanding air stability and comparable quality to bulk single crystals with trap density ( $\mathrm{n}_{\text {trap }}$ ) of $4.8 \times 10^{10} \mathrm{~cm}^{-3}$, carrier mobility $(\mu)$ of $15.7 \mathrm{~cm}^{2} \cdot \mathrm{V}^{-1} \cdot \mathrm{s}^{-1}$, and a carrier lifetime $\left(\tau_{\mathrm{r}}\right)$ of $84 \mu \mathrm{s}$. In addition, perovskite SCTF growth is a substrate-independent strategy, which would offer appealing potentials, such as SCTF/ITO for PSCs, SCTF/PET for flexible devices, SCTF/quartz for optical devices and $\mathrm{SCTF} / \mathrm{Si}$ for electronic devices, etc.

Recently, Rao et al. developed a space-limited inverse temperature crystallization (SLITC) method, in which the limited spatial module has a tripartite structure: a FTO glass, a U-style thin PTFE, and a PTFE board (Figure 5c). For the preparation of continuous and dense $\mathrm{MAPbBr}_{3}$ crystal film, the precursor solution was injected into the module and a decreased temperature gradient was applied. As a result, $\mathrm{MAPbBr}_{3}$ crystal film with a super-large area of $120 \mathrm{~cm}^{2}$ and a controllable thickness of 0.1-0.8 $\mu \mathrm{m}$ was prepared [85] (Figure 5d). 

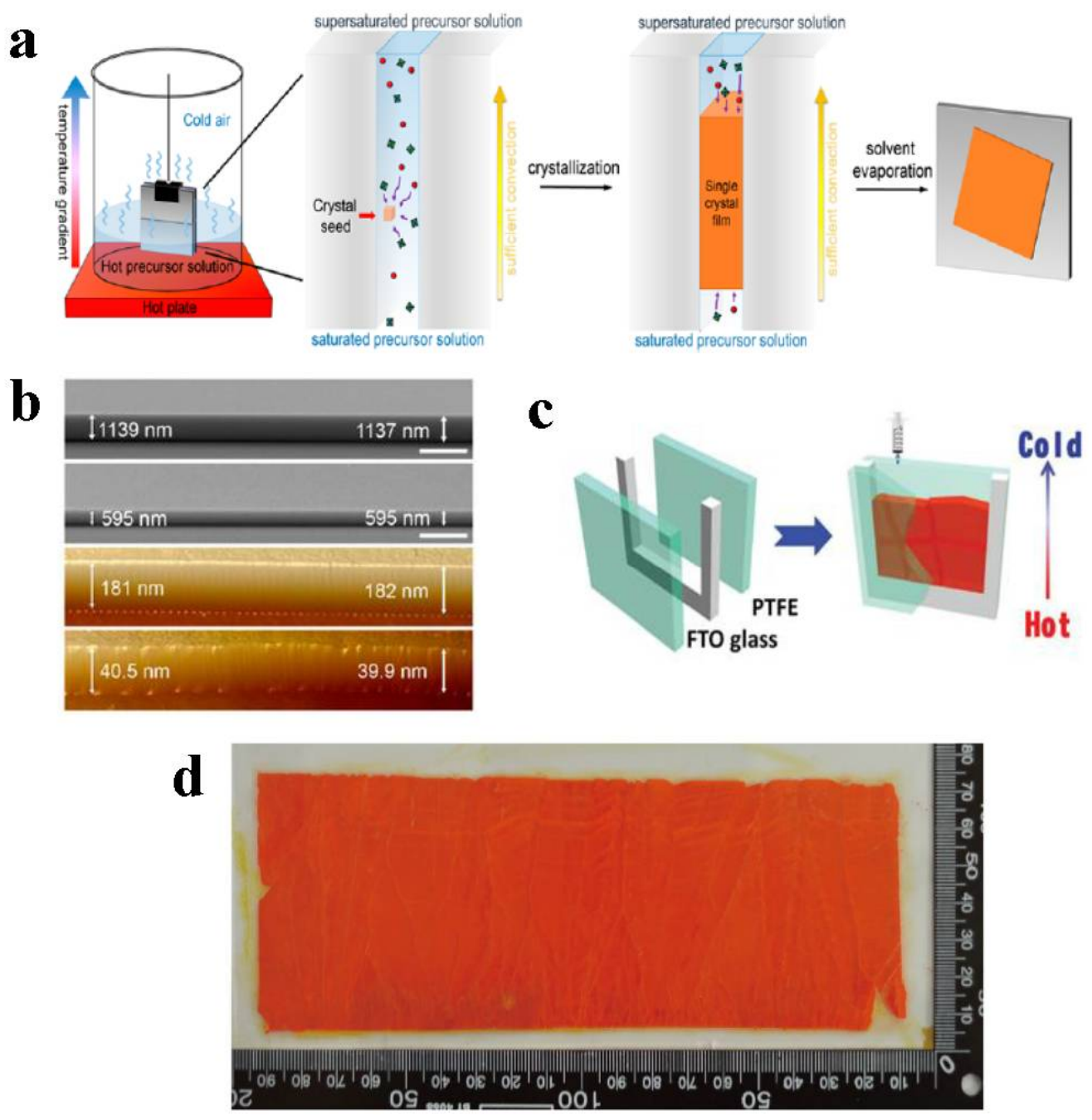

Figure 5. (a) Scheme for growth of perovskite single-crystalline thin films; and (b) Cross-section SEM images and AFM images of $\mathrm{MAPbBr}_{3}$ single-crystalline thin films with varied thicknesses. Reprinted with permission from [84], Copyright 2016, American Chemical Society; (c) Schematic diagram of the module for growing $\mathrm{MAPbBr}_{3}$ crystal films; (d) $\mathrm{MAPbBr}_{3}$ crystal films with a thickness of $0.4 \mathrm{~mm}$ and an area about $120 \mathrm{~cm}^{2}$. Reprinted with permission from [85], Copyright 2017, Wiley.

Owing to the high photoluminescence quantum yields, metal halide perovskite nanocrystals (Ncs) have also attracted great attention. Using a solvent-induced reprecipitation approach [86], $\mathrm{MAPbBr}_{3}$ NCs were first synthesized in a process in which octylammonium bromide and octadecylammonium bromide acted as surfactants to stabilize the nanocrystals for up to 3 months. Urban's group reported dilution-induced formation of hybrid perovskite nanoplatelets (NPls) [87]. This proceeded by fragmentation of the NCs into NPls, with an excess of organic ligands stabilizing the newly formed surfaces. Such fragmentation was in excellent agreement with the effects of cation intercalation and increased solvent osmotic pressure, resulting in the formation of small nanoplatelets. Vybornyi et al. reported hot injection-based synthesis [88], which was basically an ionic metathesis approach. Varying the amounts of surfactants (octylamine (OAm)/oleic acid (OA) mixture), $\mathrm{MAPbI}_{3} \mathrm{NCs}_{\text {and }}$ $\mathrm{MAPbBr}_{3}$ NPLs, NWs were successfully obtained. It was shown that the resultant NCs had poorer optical properties than those of NCs synthesized by ligand-assisted reprecipitation. Similarly, FA-based nanocrystals have received considerable interest. Protesescu et al. prepared $\mathrm{FAPbX}_{3}(\mathrm{X}=\mathrm{Br}$, I) NCs via a three-step polar solvent-free hot-injection method [89]. NCs with cubic morphology and a high photoluminescence quantum yield (PLQY) of $85 \%$ were obtained; however, its potential versatility 
was limited by the formation of phase impurities $\left(\mathrm{NH}_{4} \mathrm{~Pb}_{2} \mathrm{Br}_{5}\right)$. Manna's group synthesized $\mathrm{FAPbX}$ NCs with excellent phase purity via a modified three-precursor hot-injection technique [71] in which benzoyl halide acted as a halide precursor; thus, the metal cation sources and halide ions were not delivered together, making it possible to work with the ideal stoichiometry of ions.

\subsection{Growth of Mixed-Organic-Cation Halide Perouskite Single Crystals}

It has been reported that the mixed-organic-cation based on FA and MA halide perovskite integrates nearly all of their advantages, which include extended absorption, decreased trap-assisted recombination and enhanced ambient stability $[90,91]$. Li et al. fabricated the $\mathrm{MA}_{0.45} \mathrm{FA}_{0.55} \mathrm{PbI}_{3}$ single crystal using a modified ITC method [92]. That is, to prepare $\mathrm{MAPbI}_{3} / \mathrm{FAPbI}_{3}(1.0 \mathrm{M})$ precursor solutions, equimolar $\mathrm{PbI}_{2}$ and MAI/FAI were dissolved in $\gamma$-butyrolactone at $60{ }^{\circ} \mathrm{C}$ overnight. Subsequently, the $\mathrm{MAPbI}_{3}$ and $\mathrm{FAPbI}_{3}$ solutions were blended in a certain ratio to form the mixed-cation precursor solution. Seed crystals with sizes of $0.5-1 \mathrm{~mm}$ were obtained by placing $2 \mathrm{~mL}$ mixed-cation perovskite precursor solution in an oil bath at $160{ }^{\circ} \mathrm{C}$ for $30 \mathrm{~min}$. To obtain mixed-cation alloy perovskite crystal, a fresh precursor solution containing the corresponding seed crystal was kept at $120{ }^{\circ} \mathrm{C}$ for $3 \mathrm{~h}$. Thus, the final $\mathrm{MA}_{0.45} \mathrm{FA}_{0.55} \mathrm{PbI}_{3}$ single crystals maintained an impressive stability, and were still able to maintain their original black color after exposure in ambient air for more than 14 months (Figure 6a); however, the $\alpha-\mathrm{FAPbI}_{3}$ single crystal changed from black to yellow and $\mathrm{MAPbI}_{3}$ exhibited pale yellow spots on the surface. The carrier lifetime $\tau$ of $\mathrm{MA}_{0.45} \mathrm{FA}_{0.55} \mathrm{PbI}_{3}$ was characterized by transient photovoltaic (TPV); the TPV curves and corresponding $\tau$ are shown in Figure $6 \mathrm{~d}$,e. Compared to $\mathrm{FAPbI}_{3}$ and $\mathrm{MAPbI}_{3}$, a longer carrier lifetime of $93 \mu$ s for $\mathrm{MA}_{0.45} \mathrm{FA}_{0.55} \mathrm{PbI}_{3}$ was obtained. In another work, an ITC method assisted by hydroiodic acid for the mixed-organic-cation perovskites $\left(\mathrm{APbI}_{3}, \mathrm{~A}=\mathrm{MA}^{+}\right.$or $\left.\mathrm{FA}^{+}\right)$was developed [93]. The given $\mathrm{PbI}_{2}, \mathrm{MAI}$ and FAI were dissolved in GBL with the introduction of appropriate amount of $\mathrm{HI}$, leading to a change in chemical environment in the precursor solution and the formation of $\mathrm{APbX}_{3}-\mathrm{GBL}$, and further to $\mathrm{H}^{+}, \mathrm{MA}^{+}, \mathrm{FA}^{+}$and GBL molecules being inserted in the $\mathrm{PbI}_{2+x}{ }^{x-}$ layer. Based on the HI-assisted ITC method, $\mathrm{FA}_{(1-x)} \mathrm{MA}_{x} \mathrm{PbI}_{3}$ single crystals of millimeter size with different compositions were obtained (Figure 6b). By using time-resolved photoluminescence (TRPL) measurements, the carrier lifetimes of fresh $\mathrm{FA}_{(1-x)} \mathrm{MA}_{x} \mathrm{PbI}_{3}$ single crystals were investigated. Figure $6 \mathrm{f}$, g shows the TRPL spectra of $\mathrm{FA}_{(1-x)} \mathrm{MA}_{x} \mathrm{PbI}_{3}$ crystals with different $x$ values, and the corresponding lifetimes are summarized in Table 1 . It was found that the carrier lifetime of $\mathrm{FA}_{(1-x)} \mathrm{MA}_{x} \mathrm{PbI}_{3}(x=0.8-0.95)$ was significantly improved compared to the counterpart $\mathrm{MAPbI}_{3}$ single crystal, which disclosed the effective $\mathrm{FA}^{+}$cation doping in $\mathrm{MAPbI}_{3}$ crystal with respect to carrier behavior.

Table 1. Lifetimes extracted from the PL spectra of $\mathrm{FA}_{(1-x)} \mathrm{MA}_{x} \mathrm{PbI}_{3}$ single crystals with $x=0,0.05,0.1$, $0.15,0.2,0.8,0.85,0.9,0.95,1$.

\begin{tabular}{llllll}
\hline $\mathbf{F A}_{(\mathbf{1}-x)} \mathbf{M} \mathbf{A}_{\boldsymbol{x}} \mathbf{P b I} \mathbf{I}_{\mathbf{3}}$ & $\boldsymbol{x}=\mathbf{0}$ & $\boldsymbol{x}=\mathbf{0 . 0 5}$ & $\boldsymbol{x}=\mathbf{0 . 1}$ & $\boldsymbol{x}=\mathbf{0 . 1 5}$ & $\boldsymbol{x}=\mathbf{0 . 2}$ \\
\hline$\tau_{1}(\mathrm{~ns})$ & 91.26 & 61.43 & 52.11 & 27.26 & 31.58 \\
$\tau_{1}(\mathrm{~ns})$ & 839.31 & 689.92 & 381.86 & 579.75 & 236.74 \\
\hline $\mathbf{F A}_{(\mathbf{1}-x)} \mathbf{M A}_{\boldsymbol{x}} \mathbf{P b I}_{\mathbf{3}}$ & $\boldsymbol{x}=\mathbf{1}$ & $\boldsymbol{x}=\mathbf{0 . 9 5}$ & $\boldsymbol{x}=\mathbf{0 . 9}$ & $\boldsymbol{x}=\mathbf{0 . 8 5}$ & $\boldsymbol{x}=\mathbf{0 . 8}$ \\
\hline$\tau_{1}(\mathrm{~ns})$ & 7 & 32.45 & 122 & 88.05 & 105.3 \\
$\tau_{1}(\mathrm{~ns})$ & 145.65 & 557.5 & 1074.78 & 926.39 & 956.8 \\
\hline
\end{tabular}




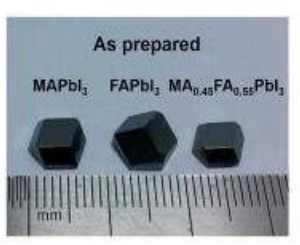

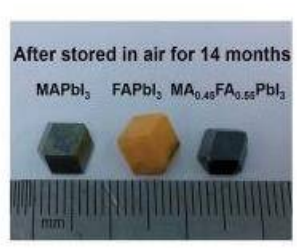

b

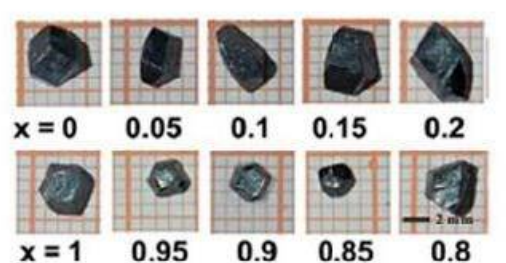

$\mathbf{c}$
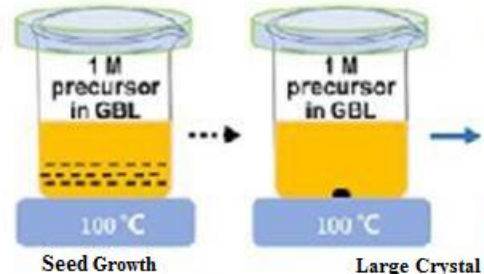

Large Crystal Growth

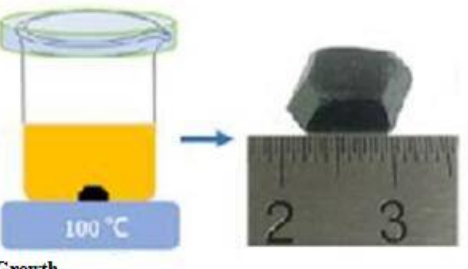

0.8
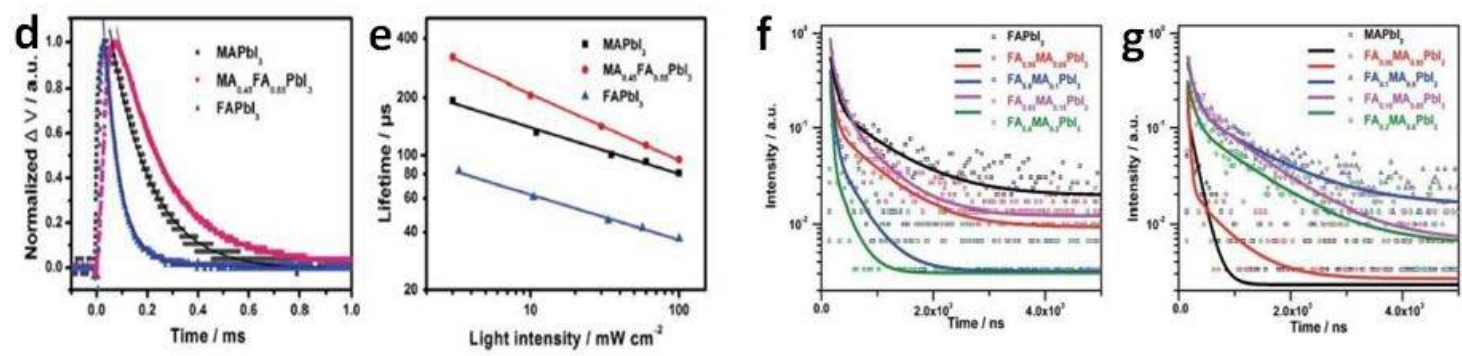

Figure 6. (a) Photographs of as-prepared $\mathrm{MAPbI}_{3}, \mathrm{FAPbI}_{3}$ and $\mathrm{MA}_{0.45} \mathrm{FA}_{0.55} \mathrm{PbI}_{3}$ single crystals and the same crystals after being stored in air for 14 months. Reprinted with permission from [92], copyright 2017, The Royal Society of Chemistry; (b) $\mathrm{FA}_{(1-x)} \mathrm{MA}_{x} \mathrm{PbI}_{3}$ single crystals with different compositions grown via HI-assisted ITC method. Reprinted with permission from [93], Copyright 2016, Royal Society of Chemisty; (c) Schematic illustration of $\left(\mathrm{FAPbI}_{3}\right)_{1-x}\left(\mathrm{MAPbBr}_{3}\right)_{x}$ crystal growth process. Reprinted with permission from [94], Copyright 2017 American Chemical Society; (d) Transient photovoltaic curves and (e) the extracted charge lifetime from TPV measurement of $\mathrm{MAPbI}_{3}, \mathrm{FAPbI}_{3}$ and $\mathrm{MA}_{0.45} \mathrm{FA}_{0.55} \mathrm{PbI}_{3}$ single crystals. Reprinted with permission from [92], copyright 2017, The Royal Society of Chemistry; Time-resolved photoluminescence spectra of $\mathrm{FA}_{(1-x)} \mathrm{MA}_{x} \mathrm{PbI}_{3}$ single crystals (f) with $x=0,0.05,0.1,0.15,0.2$ and (g) with $x=0.8,0.85,0.9,0.95$. Reprinted with permission from [93], Copyright 2016, Society of Chemisty.

Similarly, high-quality mixed-cation and -halide perovskite single crystals, with the formula $\left(\mathrm{FAPbI}_{3}\right)_{1-x}\left(\mathrm{MAPbBr}_{3}\right)_{x}(x=0,0.05,0.1,0.15,0.2)$, were also successfully grown via the ITC method [94]. The small seeds, grown at $100{ }^{\circ} \mathrm{C}$ in the precursor solution, were used to grow crystals, inducing the growth of centimeter sized single crystals, as shown in Figure 6c.

\section{Growth of Fully Inorganic Halide Perovskite Single Crystals}

Recently, $\mathrm{CsPbX}_{3}$ perovskites have rightfully been receiving attention because of their promising potential in photovoltaics [95] and bright light emission [96]. Perhaps such fully inorganic halide perovskite can overcome the chemical instability of organic-inorganic hybrid halide perovskite. It was once reported that $\mathrm{CsPbX}_{3}$ perovskite single crystals could be obtained via the Bridgmann method, a melt crystallization method, which was carried out at a high temperature and with highly pure starting reagents [97-100]. In 2008, for the first time, $\mathrm{CsPbC}_{3}$ single crystals were grown with the Bridgmann method using a process in which the precursors of the $\mathrm{PbI}_{2}$ and $\mathrm{CsCl}$ powders were sealed in a quartz crucible under vacuum [98]. In addition, $\mathrm{CsPbBr}_{3}$ single crystals were also grown using the melt crystallization method [97]. Other than the above, the fast and simple route via solution growth of hybrid halide perovskite single crystals was also used to grow inorganic $\mathrm{CsPbX}_{3}$ single crystals 
using the ITC method. Dirin et al. presented the growth of $\mathrm{CsPBr}_{3}$ single crystals under ambient atmosphere using the ITC method [101]. The optimal solvent for the growth of $\mathrm{CsPbBr}_{3}$ was reported to be DMSO. In particular, a solution of $\mathrm{CsBr}$ and $\mathrm{PbBr}_{2}(1 / 2$ by molar), dissolved in a mixed solvent of DMSO with cyclohexanol and DMF, could grow 1-3 nuclei at $90{ }^{\circ} \mathrm{C}$, and further crystal growth could take place without additional nucleation until the temperature increased to $110^{\circ} \mathrm{C}$. As a result, a flat and orange-colored $\mathrm{CsPbBr}_{3}$ single crystal of $\sim 8 \mathrm{~mm}$ in length was obtained (Figure 7).
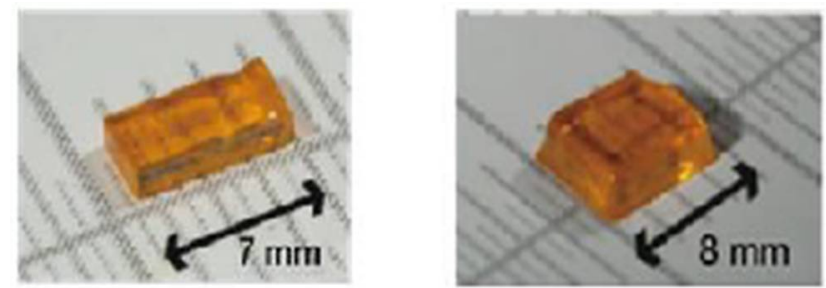

Figure 7. Photographs of the obtained $\mathrm{CsPbBr}_{3}$ single crystals. Reprinted with permission from [101], Copyright 2016, American Chemical Society.

The AVC method can be used to prepared inorganic halide perovskite, too. Rakita et al. grew $\mathrm{CsPbBr}_{3}$ single crystals from a DMSO precursor solution with $\mathrm{CsBr}$ and $\mathrm{PbBr}_{2}$ (1/1 by molar) [102]. The precursor solution was titrated by $\mathrm{MeCN}$ or $\mathrm{MeOH}$ until a saturated system was achieved. The saturated solution was filtered to use for crystal growth. During the AVC process, MeCN or $\mathrm{MeOH}$ was developed as the antisolvent. A balanced antisolvent atmosphere was created, and crystal formation occurred at room temperature; the crystal growth could be accelerated by heating the antisolvent bath. In addition, crystal growth using $\mathrm{H}_{2} \mathrm{O}$ as an antisolvent was investigated, and it was found that the orange crystals were inclined to blench. $\mathrm{CsPbBr}_{3}$ crystal growth via the ITC method was also studied by the same group. To eliminate the formation of undesirable precipitants, they developed a two-step heating cycle. The precursor solution was firstly heated to the desired temperature and allowed return to room temperature under continuous stirring. After being filtered, the final crystalline precursor solution was obtained, and orange $\mathrm{CsPbBr}_{3}$ crystals were shown after the second heating cycle. It is noted that $\mathrm{CsPbBr}$ crystals begin to appear at above $120^{\circ} \mathrm{C}$ in the $\mathrm{MeCN}$-saturated solution; however, this can occur at about $40{ }^{\circ} \mathrm{C}$ in the $\mathrm{MeOH}$-saturated solution.

Tong et al. reported high-quality colloidal $\mathrm{CsPbX}_{3}(\mathrm{X}=\mathrm{I}, \mathrm{Br}$, and $\mathrm{Cl})$ perovskite nanocrystals (NCs) [103]. The synthesis was based on direct tip sonication of precursor mixtures under ambient atmospheric conditions. This method was based on the formation of a metal-ligand complex, which was then further reduced into metal nanoparticles. Urban and Co-workers developed a single-step ligand-mediated synthesis of single-crystalline $\mathrm{CsPbBr}_{3}$ nanowires (NWs) directly from the precursor powders [104]. Through an oriented-attachment mechanism, the initially formed $\mathrm{CsPbBr}_{3}$ nanocubes were transformed into NWs, which exhibited strongly polarized emission and could self-assemble at an air/liquid interface.

In addition, $\mathrm{Cs}_{2} \mathrm{AgBiBr}_{6}$, a bismuth-halide double perovskite single crystal was also reported by Karunadasa's group [105]. To obtain the large single crystal, the precursor solution was kept at $110^{\circ} \mathrm{C}$ for $2 \mathrm{~h}$, then cooled to room temperature at a cooling rate of $1{ }^{\circ} \mathrm{C} / \mathrm{h}$. The results indicated that $\mathrm{Cs}_{2} \mathrm{AgBiBr}_{6}$ crystal had an indirect bandgap of $1.95 \mathrm{eV}$ and a long room-temperature PL lifetime of ca. $660 \mathrm{~ns}$. Table 2.

The growth methods and properties of as-grown perovskite single crystals are summarized in 
Table 2. Summary of perovskite single crystal growth methods and properties of as-grown crystals.

\begin{tabular}{|c|c|c|c|c|c|c|}
\hline \multirow[b]{2}{*}{ Single Crystal } & \multirow{2}{*}{$\begin{array}{l}\text { Growth } \\
\text { Method }\end{array}$} & \multirow[b]{2}{*}{ Size (mm) } & \multirow[b]{2}{*}{ Growth Period } & \multicolumn{2}{|l|}{ Properties } & \multirow[b]{2}{*}{ Ref. } \\
\hline & & & & $\begin{array}{l}\text { Carrier Mobility } \\
\left(\mathrm{cm}^{2} \cdot \mathrm{V}^{-1} \cdot \mathrm{s}^{-1}\right)\end{array}$ & $\begin{array}{l}\text { Trap State } \\
\text { Density }\left(\mathrm{cm}^{-3}\right)\end{array}$ & \\
\hline $\mathrm{MAPbI}_{3}$ & & $2-3$ & $48 \mathrm{~h}$ & & & [60] \\
\hline $\mathrm{CH}_{3} \mathrm{NH}_{3} \mathrm{PbBr}_{3}$ & & 5 & More than 10 days & & & [60] \\
\hline $\mathrm{MAPbI}_{3}$ & & $10 \times 10 \times 8$ & & & & [61] \\
\hline $\mathrm{MAPbI}_{3}$ & STL & $12 \times 12 \times 7$ & $2-4$ weeks & $105 \pm 35$ & $10^{10}$ & [62] \\
\hline $\mathrm{MAPbI}_{3}$ & & $20 \times 18 \times 6$ & 5 days & & & [63] \\
\hline $\mathrm{CH}_{3} \mathrm{NH}_{3} \mathrm{PbI}_{3}(\mathrm{Cl})$ & & $20 \times 18 \times 6$ & 5 days & $167 \pm 35$ & $7.6 \times 10^{8}$ & [66] \\
\hline $\mathrm{MAPbI}_{3}$ & & $71 \times 54 \times 39$ & & 34 & $1.4 \times 10^{10}$ & [71] \\
\hline $\mathrm{MAPbCl}_{3}$ & & 7 & 3 days & 179 & $1.8 \times 10^{9}$ & [71] \\
\hline $\mathrm{MAPbBr}_{3}$ & ITC & $11 \times 11 \times 4$ & & 4.36 & $2.6 \times 10^{10}$ & [71] \\
\hline $\mathrm{FPbI}_{3}$ & & 5 & & 4.4 & $1.5 \times 10^{11}$ & [76] \\
\hline $\mathrm{MA}_{0.45} \mathrm{FA}_{0.55} \mathrm{PbI}_{3}$ & & 8 & $4 \mathrm{~h}$ & $271 \pm 60$ & $2.6 \times 10^{9}$ & [86] \\
\hline $\mathrm{CH}_{3} \mathrm{NH}_{3} \mathrm{PbBr}_{3}$ & AVC & $1.4 \times 1.4 \times 0.7$ & & & $10^{9}-10^{10}$ & [78] \\
\hline
\end{tabular}

\section{Application of Halide Perovskite Single Crystals}

Through the CATC method, Bakr's group grew hybrid perovskite monocrystalline films and carried out explorative study for the first time on perovskite monocrystalline solar cells with two simple device structures, i.e., ITO/ $\mathrm{MAPbBr}_{3} / \mathrm{Au}$ and $\mathrm{FTO} / \mathrm{TiO}_{2} / \mathrm{MAPbBr}_{3} / \mathrm{Au}$ [82]. Figure 8 shows the photoelectric characteristics of those monocrystalline solar cells. Without any HTLs and ETLs, the optimized solar cell of ITO/MAPbBr $3(4 \mu \mathrm{m}) / \mathrm{Au}$ offers an ultra-stable photoelectric conversion efficiency (PCE) of over 5\% and close to 100\% IQE (Figure 8a,c). Furthermore, for the p-n-junction-based architecture, near 100\% IQE and higher efficiency (6.5\%) than the best HTL-free $\mathrm{MAPbBr}_{3}$ solar cells was achieved (Figure 8b,d). These significant works made clear that the optoelectronic properties of monocrystalline-film-based devices are superior to their polycrystalline counterparts. Interestingly, based on the bulk single crystal, Huang's group fabricated a lateral-structured device with a maximum PCE of $5.36 \%$ at $170 \mathrm{~K}$ and a comparable $J_{S C}$ to the best thin-film solar cells [106].
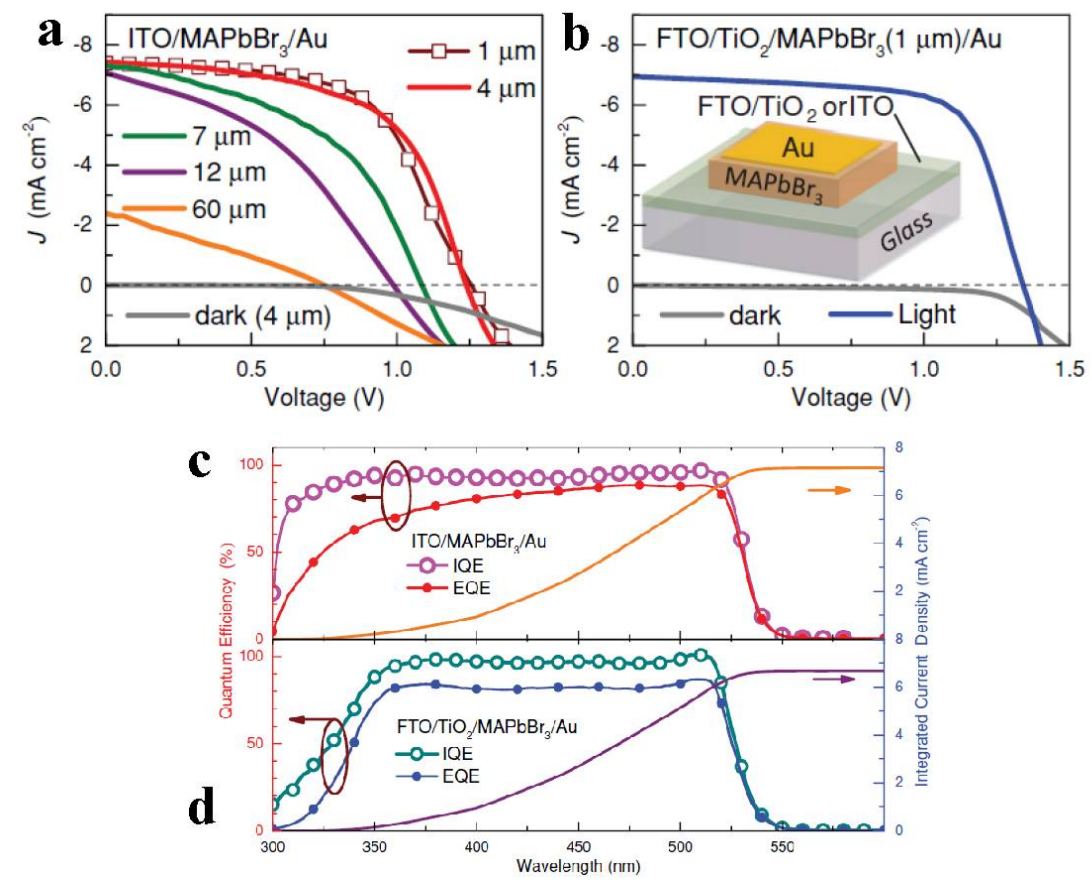

Figure 8. Illuminated and dark $J-V$ curves, wavelength-dependent $I Q E$ and $E Q E$ : (a,c) ITO-based and (b,d) $\mathrm{FTO} / \mathrm{TiO}_{2}$-based monocrystalline film solar cells. Reprinted with permission from [82], Copyright 2016, Wiley. 
Photodetectors are another device for realizing photoelectric conversion, and have attracted much attention because of their extensive applications, which include biological sensing, camera imaging, missile warning, and communication [107-110]. Organic-inorganic hybrid perovskite single crystals have also been utilized to fabricate photodetectors [111-113]. Lian et al. firstly fabricated high-performance planar-type photodetector on the (100) facet of $\mathrm{MAPbI}_{3}$ single crystal [61]. The spectral responsivity $(R)$ and $E Q E$, the crucial parameters for photodetectors, were measured and calculated. For MSCP $\left(\mathrm{MAPbI}_{3}\right.$ single crystal photodetector) and $\mathrm{MPFP}\left(\mathrm{MAPbI}_{3}\right.$ polycrystalline film photodetector), the $R$ values were estimated to be $2.55 \mathrm{~A} \mathrm{~W}^{-1}$ and $0.0197 \mathrm{~A} \mathrm{~W}^{-1}$, respectively, with the corresponding EQE values calculated to be $5.95 \times 10^{2} \%$ and $4.59 \%$, respectively (Figure $9 a$ ), which are over two orders of magnitude higher than the $R$ and $E Q E$ values obtained for MSCP. Furthermore, the photoresponse times of MSCP ( $74 \mu \mathrm{s}$ and $58 \mu \mathrm{s}$ for the rise time and decay time, respectively) were about three orders of magnitude faster than those for MPFP (52 ms and $36 \mathrm{~ms}$ for the rise time and decay time, respectively) (Figure $9 \mathrm{~b}$ ).
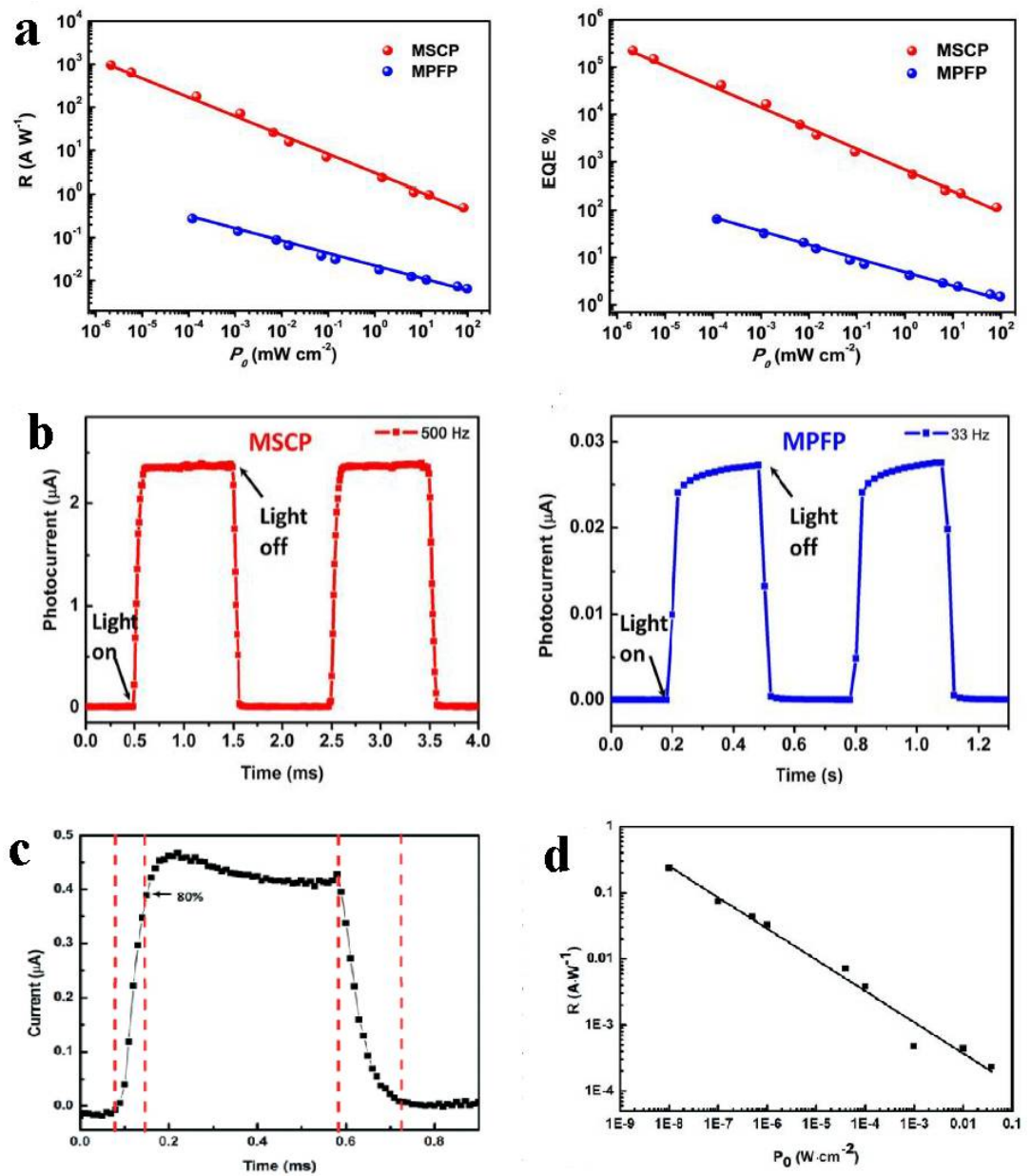

Figure 9. (a) Responsivity, external quantum efficiency EQE; and (b) Transient photocurrent response for as-fabricated MSCP and MPFP. Reprinted with permission from [61], Copyright 2015, Springer; (c) Time response of the $\mathrm{MAPbI}_{3}$ perovskite photodetector; and (d) Responsivity of $\mathrm{MAPbI}_{3}$ single crystal photodetector at different radiance power. Reprinted with permission from [114], copyright 2016, The Royal Society of Chemistry.

Ding et al. fabricated a self-powered $\mathrm{MAPbI}_{3}$ perovskite single crystal photodetector with $\mathrm{Au}-\mathrm{Al}$ electrodes [114], which exhibited a fast rise and decay time of $71 \mu \mathrm{s}$ and $112 \mu \mathrm{s}$ (Figure 9c). A good $R$ value of $0.24 \mathrm{~A} \mathrm{~W}^{-1}$ at the lowest incident power density of $1 \times 10^{-8} \mathrm{~W} \mathrm{~cm}^{-2}$ was demonstrated (Figure 9d). 
Liu's group reported a $\mathrm{MAPbI}_{3}$ single-crystalline wafer photodetector [83] that showed a photocurrent response about 350 times higher than that of the microcrystalline thin film detector. Moreover, nearly 100 photodetectors were fabricated on a piece of single-crystalline perovskite wafer (Figure 10a), highlighting the feasibility of batch-processing integrated circuits on ultrathin single-crystalline wafers. In addition, they fabricated $\mathrm{FAPbI}_{3}$-wafer-based photodetectors, which exhibited a photoresponse 90 times higher than its thin-film perovskite counterpart. Furthermore, an array of more than 150 photodetectors were also designed on a piece of thin wafer. Using $\mathrm{MAPbBr}_{3}$ single crystal, Shaikh et al. constructed Schottky-type photodetectors [115]. These devices exhibited response times on the scale of $100 \mu \mathrm{s}$ and a photodetectivity of $1.4 \times 10^{10}$ Jones at zero bias. Recently, narrowband photodetector devices based on large-area $\mathrm{MAPbBr}_{3}$ crystal films have been studied [85], which has enabled high narrow response under a low bias of $-1 \mathrm{~V}$, a broad linear response range of $10^{-4}-10^{2} \mathrm{~mW} \mathrm{~cm} \mathrm{~cm}^{-2}$ and $3 \mathrm{~dB}$ cutoff frequency $\left(\mathrm{f}_{3 \mathrm{~dB}}\right)$ of $\sim 110 \mathrm{kHz}$. Different from one-component single-crystal perovskite photodetectors, a core-shell heterojunction photodetector based on $\mathrm{MAPbBr}_{3}$ single crystal was developed [116]. It was found that the photodetector offered the feature of self-power and exhibited a peak $\mathrm{R}$ of $11.5 \mathrm{~mA} \mathrm{~W}^{-1}$ at zero bias under $450 \mathrm{~nm}$, which was one order of magnitude higher than that of $\mathrm{MAPbBr}_{3}$ single crystal. The EQE of $3.17 \%$ was also much higher than the reported $\mathrm{MAPbBr}_{3}$ single crystal $(0.2 \%)$. The high-quality $\mathrm{MAPbCl}_{3}$ crystals for $\mathrm{UV}$ photodetection were grown using DMSO-DMF solution. This demonstrated that the $\mathrm{MAPbCl}_{3}$ single crystal-based UV-photodetector possessed an on-off ratio as high as $1.1 \times 10^{3}$ and a calculated detectivity of $1.2 \times 10^{10}$ Jones. Li et al. reported that the mixed cation $\mathrm{MA}_{0.45} \mathrm{FA}_{0.55} \mathrm{PbI}_{3}$ perovskite single crystal

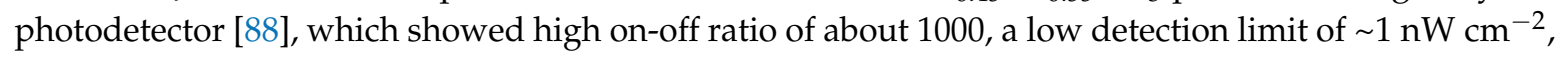
and a short response time of less than $200 \mu \mathrm{s}$. It is noted that the photodetector showed stable characteristics for a long period at both zero and $-1 \mathrm{~V}$ bias, as shown in Figure $10 \mathrm{~d}$.

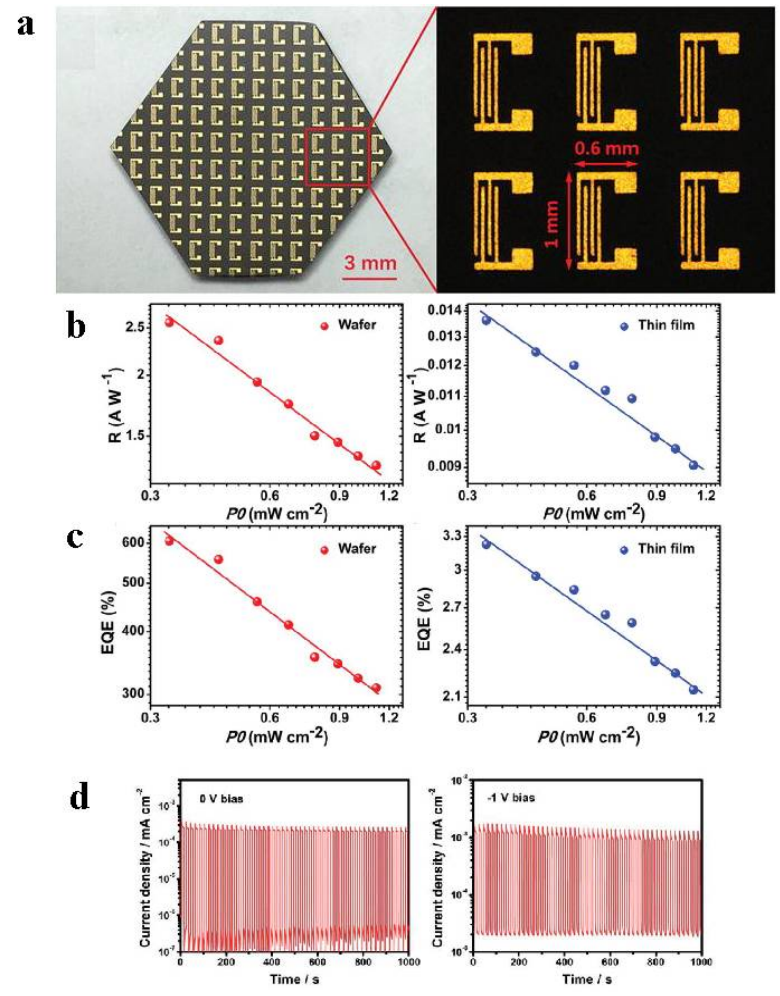

Figure 10. (a) Photograph of $\approx 100$ photodetectors fabricated on a single-crystalline wafer; (b) $R$ and (c) $E Q E$ of a detector made of single-crystalline perovskite wafer and microcrystalline perovskite thin film. Reprinted with permission from [83], Copyright 2017, Wiley; (d) Stability test of $\mathrm{MA}_{0.45} \mathrm{FA}_{0.55} \mathrm{PbI}_{3}$ perovskite single crystal photodetector at $0 \mathrm{~V}$ and $-1 \mathrm{~V}$ bias. Reprinted with permission from [88], copyright 2017, The Royal Society of Chemistry. 
Further, owing to the excellent carrier transport properties, metal halide perovskite single crystals can also be used in high-energy ray detectors, which are able to convert some high-energy rays like $\mathrm{X}$-ray and $\gamma$-ray photons into charges. Using the $\mathrm{MAPbI}_{3}$ films, an X-ray detector with responsivity of $1.9 \times 10^{-4}$ carriers/photon was first reported [117]. Based on bulk MAPbBr 3 single crystal, through structural optimization and surface passivation, Wei et al. fabricated the $\mathrm{X}$-ray detector and obtained a detector with a sensitivity of $80 \mu \mathrm{C} \cdot \mathrm{mGy}_{\text {air }}{ }^{-1} \cdot \mathrm{cm}^{-2}[118]$.

\section{Summary and Future Perspectives}

Metal hybrid perovskites have been extensively studied for solar cells, photodetectors, lasing, light-emitting diodes, etc., owing mainly to their excellent semiconductor properties, low cost and facile deposition techniques. It is noted that metal hybrid perovskite single crystals show remarkably low trap-state densities and long carrier diffusion lengths, which can even compare with the best photovoltaic-quality silicon. These properties enable metal hybrid perovskite single crystals to act as desirable semiconductors for optoelectronic applications. This review focuses on the recent progress in the growth and application of different metal hybrid perovskite single crystals. Single- and mixed-organic-cation halide perovskite single crystals can be prepared in solution, with the STL process having been demonstrated to be an effective method. To grow large-sized and high-quality single crystals, the seed-assisted growth method was developed, and centimeter-sized single crystals were obtained. However, STL is a time-consuming process. The ITC and AVC methods are improved processes that have been widely investigated for growth of high-quality single crystals. It is noted that the fully inorganic halide perovskite single crystals can be grown by solution process. The preparation of the above metal hybrid halide perovskite single crystals may contribute to their further application research.

To date, optoelectronic devices based on perovskite single crystals are gradually being considered. The brilliant performance of single-crystal-based photodetectors is further testimony to the benefits of metal hybrid halide perovskite materials. However, the application in solar cells based on single crystals is still limited because of the lack of high-quality monocrystal films with appropriate thickness for perovskite solar cells. In the future, the preparation of high-quality perovskite single crystals with controlled thickness and orientation able to meet the requirements of this application is urgently needed.

Author Contributions: Shuigen Li, Jian-Qiao Meng and Shunjian $\mathrm{Xu}$ conceived and designed the analyzed, Shuigen Li, Chen Zhang, Jiao-Jiao Song and Xiaohu Xie collected the data. Shuigen Li, Jian-Qiao Meng and Shunjian $\mathrm{Xu}$ wrote the paper.

Acknowledgments: This work was supported by China 1000-Young Talents Plan, the National Natural Science Foundation of China $(51203192,61172047,51673214)$, the Jiangxi Provincial Natural Science Foundation of China (GJJ171063, GJJ171060, GJJ171066).

Conflicts of Interest: The authors declare no conflict of interest.

\section{References}

1. Burschka, J.; Pellet, N.; Moon, S.-J.; Humphry-Baker, R.; Gao, P.; Nazeeruddin, M.K.; Grätzel, M. Sequential deposition as a route to high-performance perovskite-sensitized solar cells. Nature 2013, 499, 316-319. [CrossRef] [PubMed]

2. Heo, J.H.; Im, S.H.; Noh, J.H.; Mandal, T.N.; Lim, C.-S.; Chang, J.A.; Lee, Y.H.; Kim, H.J.; Sarkar, A.; Nazeeruddin, M.K.; et al. Efficient inorganic organic hybrid heterojunction solar cells containing perovskite compound and polymeric hole conductors. Nat. Photonics 2013, 7, 486-491. [CrossRef]

3. Im, J.-H.; Lee, C.-R.; Lee, J.-W.; Park, S.-W.; Park, N.-G. 6.5\% Efficient Perovskite Quantum-Dot-Sensitized Solar Cell. Nanoscale 2011, 3, 4088-4093. [CrossRef] [PubMed]

4. $\quad$ Kim, H.-S.; Lee, C.-R.; Im, J.-H.; Lee, K.-B.; Moehl, T.; Marchioro, A.; Moon, S.-J.; Humphry-Baker, R.; Yum, J.-H.; Moser, J.E.; et al. Lead iodide perovskite sensitized all-solid-state submicron thin film mesoscopic solar cell with efficiency exceeding 9\%. Sci. Rep. 2012, 2, 591. [CrossRef] [PubMed] 
5. Kojima, A.; Teshima, K.; Shirai, Y.; Miyasaka, T. Organometal halide perovskites as visible-light sensitizers for photovoltaic cells. J. Am. Chem. Soc. 2009, 131, 6050-6051. [CrossRef] [PubMed]

6. Zhao, Y.; Zhu, K.C. Organic-inorganic hybrid lead halide perovskites for optoelectronic and electronic applications. Chem. Soc. Rev. 2016, 45, 655-689. [CrossRef] [PubMed]

7. Tiep, N.H.; Ku, Z.; Fan, H.J. Recent advances in improving the stability of perovskite solar cells. Adv. Energy Mater. 2016, 6, 1501420. [CrossRef]

8. Lü, X.; Wang, Y.; Stoumpos, C.C.; Hu, Q.; Guo, X.; Chen, H.; Yang, L.; Smith, J.S.; Yang, W.; Zhao, Y.; et al. Enhanced Structural Stability and Photo Responsiveness of $\mathrm{CH}_{3} \mathrm{NH}_{3} \mathrm{SnI}_{3}$ Perovskite via Pressure-Induced Amorphization and Recrystallization. Adv. Mater. 2016, 28, 8663-8668. [CrossRef] [PubMed]

9. Jeon, N.J.; Noh, J.H.; Yang, W.S.; Kim, Y.C.; Ryu, S.; Seo, J.; Seok, S.I. Compositional Engineering of Perovskite Materials for High-Performance Solar Cells. Nature 2015, 517, 476-480. [CrossRef] [PubMed]

10. Albero, J.; Asiri, A.M.; Garcia, H.; Mater, J. Influence of the composition of hybrid perovskites on their performance in solar cells. J. Mater. Chem. A 2016, 4, 4353-4364. [CrossRef]

11. Chen, J.; Zhou, S.; Jin, S.; Li, H.; Zhai, T. Crystal organometal halide perovskites with promising optoelectronic applications. Mater. Chem. C 2016, 4, 11-27. [CrossRef]

12. Prochowicz, D.; Franckevičius, M.; Cieślak, A.M.; Zakeeruddin, S.M.; Grätzel, M.; Lewiński, J. Mechanosynthesis of the hybrid perovskite $\mathrm{CH}_{3} \mathrm{NH}_{3} \mathrm{PbI}_{3}$ : Characterization and the corresponding solar cell efficiency. Mater. J. Chem. A 2015, 3, 20772-20777. [CrossRef]

13. Harikesh, P.C.; Mulmudi, H.K.; Ghosh, B.; Goh, T.W.; Teng, T.; Thirumal, K.; Lockrey, M.; Weber, K.; Koh, T.M.; Li, S.; et al. Rb as an Alternative Cation for Templating Inorganic Lead-Free Perovskites for Solution Processed Photovoltaics. Chem. Mater. 2016, 28, 7496-7504. [CrossRef]

14. Cheng, Y.; Li, H.-W.; Zhang, J.; Yang, Q.-D.; Liu, T.; Guan, Z.; Qing, J.; Lee, C.; Tsang, S.-W. Spectroscopic study on the impact of methyl ammonium iodide loading time on the electronic properties in perovskite thin films. Mater. J. Chem. A 2016, 4, 561-567. [CrossRef]

15. Eperon, G.E.; Stranks, S.D.; Menelaou, C.; Johnston, M.B.; Herz, L.M.; Snaith, H.J. Formamidinium lead trihalide: A broadly tunable perovskite for efficient planar heterojunction solar cells. Energy Environ. Sci. 2014, 7, 982-988. [CrossRef]

16. Leyden, M.R.; Lee, M.V.; Raga, S.R.; Qi, Y. Large formamidinium lead trialed perovskite solar cells using chemical vapor deposition with high reproducibility and tunable chlorine concentrations. Mater. J. Chem. A 2015, 3, 16097-16103. [CrossRef]

17. Eperon, G.E.; Beck, C.E.; Snaith, H.J. Cation exchange for thin film lead iodide perovskite interconversion. Mater. Horiz. 2016, 3, 63-71. [CrossRef]

18. Pellet, N.; Gao, P.; Gregori, G.; Yang, T.-Y.; Nazeeruddin, M.K.; Maier, J.; Grätzel, M. Mixed-Organic-Cation Perovskite Photovoltaics for Enhanced Solar-Light Harvesting. Angew. Chem. Int. Ed. 2014, 53, 3151-3157. [CrossRef] [PubMed]

19. Starr, D.E.; Sadoughi, E.; Handick, E.; Wilks, G.; Alsmeier, J.H.; Köhler, L.; Gorgoi, M.; Snaith, H.J.; Bär, M. Direct observation of an inhomogeneous chlorine distribution in $\mathrm{CH}_{3} \mathrm{NH}_{3} \mathrm{PbI}_{3-\mathrm{x}} \mathrm{Cl}_{\mathrm{x}}$ layers: Surface depletion and interface enrichment. Energy Environ. Sci. 2015, 8, 1609-1615. [CrossRef]

20. Huang, Z.; Hu, Z.; Yue, G.; Liu, J.; Cui, X.; Zhang, J.; Zhu, Y. $\mathrm{CH}_{3} \mathrm{NH}_{3} \mathrm{PbI}_{3-\mathrm{x}} \mathrm{Clx}$ films with coverage approaching $100 \%$ and with highly oriented crystal domains for reproducible and efficient planar heterojunction perovskite solar cells. Phys. Chem. Chem. Phys. 2015, 17, 22015-22022. [CrossRef] [PubMed]

21. Brenner, T.M.; Egger, D.A.; Kronik, L.; Hodes, G.; Cahen, D. Hybrid organic-inorganic perovskites: Low-cost semiconductors with intriguing charge-transport properties. Nat. Rev. Mater. 2016, 1, 15007. [CrossRef]

22. Heo, J.H.; Im, S.H. Highly reproducible, efficient hysteresis-less $\mathrm{CH}_{3} \mathrm{NH}_{3} \mathrm{PbI}_{3-\mathrm{x}} \mathrm{Cl}_{\mathrm{x}}$ planar hybrid solar cells without requiring heat-treatment. Nanoscale 2016, 8, 2554-2560. [CrossRef] [PubMed]

23. Kim, T.G.; Seo, S.W.; Kwon, H.; Hahn, J.; Kim, J.W. Influence of halide precursor type and its composition on the electronic properties of vacuum deposited perovskite films. Phys. Chem. Chem. Phys. 2015, 17, 24342-24348. [CrossRef] [PubMed]

24. Jiang, M.; Wu, J.; Lan, F.; Tao, Q.; Gao, D.; Li, G. Enhancing the performance of planar organo-lead halide perovskite solar cells by using a mixed halide source. Mater. J. Chem. A 2014, 3, 963-967. [CrossRef]

25. Qing, J.; Chandran, H.-T.; Cheng, Y.-H.; Liu, X.-K.; Li, H.-W.; Tsang, S.-W.; Lo, M.-F.; Lee, C.-S. Chlorine Incorporation for Enhanced Performance of Planar Perovskite Solar Cell Based on Lead Acetate Precursor. ACS Appl. Mater. Interfaces 2015, 7, 23110-23116. [CrossRef] [PubMed] 
26. Zhang, W.; Saliba, M.; Moore, D.T.; Pathak, S.K.; Hörantner, M.T.; Stergiopoulos, T.; Stranks, S.D.; Eperon, G.E.; Alexander-Webber, J.A.; Abate, A.; et al. Ultrasmooth organic-inorganic perovskite thin-film formation and crystallization for efficient planar heterojunction solar cells. Nat. Commun. 2015, 6, 6142. [CrossRef] [PubMed]

27. Dharani, S.; Dewi, H.A.; Prabhakar, R.R.; Baikie, T.; Shi, C.; Yonghua, D.; Mathews, N.; Boix, P.P.; Mhaisalkar, S.G. Incorporation of $\mathrm{Cl}$ into sequentially deposited lead halide perovskite films for highly efficient mesoporous solar cells. Nanoscale 2014, 6, 13854-13860. [CrossRef] [PubMed]

28. Bhalla, A.S.; Guo, R.; Roy, R. The perovskite structure-a review of its role in ceramic science and technology. Mater. Res. Innov. 2000, 4, 3-26. [CrossRef]

29. Borriello, I.; Cantele, G.; Ninno, D. Ab initio investigation of hybrid organic-inorganic perovskites based on tin halides. Phys. Rev. B 2008, 77, 235214. [CrossRef]

30. Søndenå, R.; Ravindran, P.; Stølen, S.; Grande, T.; Hanfland, M. Electronic structure and magnetic properties of cubic and hexagonal $\mathrm{SrMnO}_{3}$. Phys. Rev. B 2006, 74, 144102. [CrossRef]

31. Mitzi, D.B. Organic-Inorganic Perovskites Containing Trivalent Metal Halide Layers: The Templating Influence of the Organic Cation Layer. Inorg. Chem. 2000, 39, 6107-6113. [CrossRef] [PubMed]

32. Johnston, M.B.; Herz, L.M. Hybrid Perovskites for Photovoltaics: Charge-Carrier Recombination, Diffusion, and Radiative Efficiencies. Acc. Chem. Res. 2016, 49, 146-154. [CrossRef] [PubMed]

33. Noel, N.K.; Stranks, S.D.; Abate, A.; Wehrenfennig, C.; Guarnera, S.; Haghighirad, A.-A.; Sadhanala, A.; Eperon, G.E.; Pathak, S.K.; Johnston, M.B.; et al. Lead-free organic-inorganic tin halide perovskites for photovoltaic applications. Energy Environ. Sci. 2014, 7, 3061-3068. [CrossRef]

34. Hao, F.; Stoumpos, C.C.; Cao, D.H.; Chang, R.P.H.; Kanatzidis, M.G. Lead-Free Solid-State Organic-Inorganic Halide Perovskite Solar Cells. Nat. Photonics 2014, 8, 489-494. [CrossRef]

35. Hoke, E.T.; Slotcavage, D.J.; Dohner, E.R.; Bowring, A.R.; Karunadasa, H.I.; McGehee, M.D. Reversible photo-induced trap formation in mixed- halide hybrid perovskites for photovoltaics. Chem. Sci. 2015, 6, 613-617. [CrossRef] [PubMed]

36. Suarez, B.; Gonzalez-Pedro, V.; Ripolles, T.S.; Sanchez, R.S.; Otero, L.; Mora-Sero, I. Recombination Study of Combined Halides (Cl, Br, I) Perovskite Solar Cells. Phys. J. Chem. Lett. 2014, 5, 1628-1635. [CrossRef] [PubMed]

37. Park, N.-G. Perovskite solar cells: An emerging photovoltaic technology. Mater. Today 2015, 18, 65-72. [CrossRef]

38. Shen, Q.; Ogomi, Y.; Chang, J.; Toyoda, T.; Fujiwara, K.; Yoshino, K.; Sato, K.; Yamazaki, K.; Akimoto, M.; Kuga, Y.; et al. Optical absorption, charge separation and recombination dynamics in $\mathrm{Sn} / \mathrm{Pb}$ cocktail perovskite solar cells and their relationships to photovoltaic performances. Mater. J. Chem. A 2015, 3, 9308-9316. [CrossRef]

39. Koren, E.; Lortscher, E.; Rawlings, C.; Knoll, A.W.; Duerig, U. Adhesion and friction in mesoscopic graphite contacts. Science 2015, 348, 679-683. [CrossRef] [PubMed]

40. Shi, D.; Adinolfi, V.; Comin, R.; Yuan, M.; Alarousu, E.; Buin, A.; Chen, Y.; Hoogl, S.; Rothenberger, A.; Katsiev, K.; et al. Low trap-state density and long carrier diffusion in organolead trihalide perovskite single crystals. Science 2015, 347, 519-522. [CrossRef] [PubMed]

41. Li, C.; Wang, F.; Xu, J.; Yao, J.; Zhang, B.; Zhang, C.; Xiao, M.; Dai, S.; Li, Y.; Tan, Z. Efficient perovskite/fullerene planar heterojunction solar cells with enhanced charge extraction and suppressed charge recombination. Nanoscale 2015, 7, 9771-9778. [CrossRef] [PubMed]

42. Wang, Y.; Wang, H.; Yu, M.; Fu, F.; Qin, Y.; Zhang, J.; Ai, X. Trap-limited charge recombination in intrinsic perovskite film and meso-superstructured perovskite solar cells and the passivation effect of the hole-transport material on trap states. Phys. Chem. Chem. Phys. 2015, 17, 29501-29506. [CrossRef] [PubMed]

43. Troughton, J.; Carnie, M.J.; Davies, M.L.; Charbonneau, C.; Jewell, E.H.; Worsley, D.A.; Watson, T.M.; Mater, J.; Watson, T. Photonic flash-annealing of lead halide perovskite solar cells in 1 ms. Mater. J. Chem. A 2016, 4, 3471-3476. [CrossRef]

44. Seetharaman, S.M.; Nagarjuna, P.; Kumar, P.N.; Singh, S.P.; Deepa, M.; Namboothiry, M.A. Efficient organic-inorganic hybrid perovskite solar cells processed in air. Phys. Chem. Chem. Phys. 2014, 16, 24691-24696. [CrossRef] [PubMed]

45. Wang, H.-Y.; Wang, Y.; Yu, M.; Han, J.; Guo, Z.-X.; Ai, X.-C.; Zhang, J.; Qin, Y. Mechanism of biphasic charge recombination and accumulation in $\mathrm{TiO}_{2}$ mesoporous structured perovskite solar cells. Phys. Chem. Chem. Phys. 2016, 18, 12128-12134. [CrossRef] [PubMed] 
46. Zhao, J.; Wang, P.; Wei, L.; Liu, Z.; Fang, X.; Liu, X.; Ren, D.; Mai, Y. Efficient charge-transport in hybrid lead iodide perovskite solar cells. Dalton Trans. 2015, 44, 16914-16922. [CrossRef] [PubMed]

47. Bi, C.; Shao, Y.; Yuan, Y.; Xiao, Z.; Wang, C.; Gao, Y.; Huang, J. Understanding the formation and evolution of interdiffusion grown organolead halide perovskite thin films by thermal annealing. Mater. J. Chem. A 2014, 2, 18508-18514. [CrossRef]

48. Wang, B.; Wong, K.Y.; Yang, S.; Chen, T. Crystallinity and defect state engineering in organo-lead halide perovskite for high-efficiency solar cells. Mater. J. Chem. A 2016, 4, 3806-3812. [CrossRef]

49. Yang, S.Y.; Park, B.-W.; Jung, E.H.; Jeon, N.J.; Kim, Y.C.; Lee, D.U.; Shin, S.S.; Seo, J.; Kim, E.K.; Noh, J.H.; et al. Iodide management in formamidinium-lead-halide-based perovskite layers for efficient solar cells. Science 2017, 356, 1376-1379. [CrossRef] [PubMed]

50. Xing, G.; Mathews, N.; Lim, S.S.; Yantara, N.; Liu, X.; Sabba, D.; Grätzel, M.; Mhaisalkar, S.; Sum, T.C. Low-temperature solution-processed wavelength-tunable perovskites for lasing. Nat. Mater. 2014, 13, 476-480. [CrossRef] [PubMed]

51. Guo, Y.; Liu, C.; Tanaka, H.; Nakamura, E. Air-stable and solution-processable perovskite photodetectors for solar-blind UV and visible light. J. Phys. Chem. Lett. 2015, 6, 535-539. [CrossRef] [PubMed]

52. Tan, Z.-K.; Moghaddam, R.S.; Lai, M.L.; Docampo, P.; Higler, R.; Deschler, F.; Price, M.; Sadhanala, A.; Pazos, L.M.; Credgington, D.; et al. Bright light-emitting diodes based on organometal halide perovskite. Nat. Nanotechnol. 2014, 9, 687-692. [CrossRef] [PubMed]

53. He, Y.; Galli, G. Perovskites for solar thermoelectric applications: A first principle study of $\mathrm{CH}_{3} \mathrm{NH}_{3} \mathrm{AI}_{3}$ (A = Pb and Sn). Chem. Mater. 2014, 26, 5394-5400. [CrossRef]

54. Da, P.; Cha, M.; Sun, L.; Wu, Y.; Wang, Z.S.; Zheng, G. High-performance perovskite photoanode enabled by Ni passivation and catalysis. Nano Lett. 2015, 15, 3452-3457. [CrossRef] [PubMed]

55. Dong, Q.; Fang, Y.; Shao, Y.; Mulligan, P.; Qiu, J.; Cao, L.; Huang, J. Electron-hole diffusion lengths $>175 \mathrm{~m}$ in solution-grown $\mathrm{CH}_{3} \mathrm{NH}_{3} \mathrm{PbI}_{3}$ single crystals. Science 2015, 347, 967-970. [CrossRef] [PubMed]

56. Weber, $\mathrm{D}$. $\mathrm{CH}_{3} \mathrm{NH}_{3} \mathrm{PbX}_{3}$, ein $\mathrm{Pb}$ (II)-system mit kubischer perowskitstruktur $/ \mathrm{CH}_{3} \mathrm{NH}_{3} \mathrm{PbX}_{3}$, a $\mathrm{Pb}$ (II)-system with cubic perovskite structure. Z. Naturforsch. B 1978, 33, 1443-1445. [CrossRef]

57. Weber, D. $\mathrm{CH}_{3} \mathrm{NH}_{3} \mathrm{SnBrxI}_{3-\mathrm{x}}(\mathrm{x}=0-3)$, ein $\mathrm{Sn}$ (II)-system mit kubischer perowskitstruktur $/ \mathrm{CH}_{3} \mathrm{NH}_{3} \mathrm{SnBr}_{\mathrm{x}} \mathrm{I}_{3-\mathrm{x}}$ $(\mathrm{x}=0-3)$, a Sn(II)-system with cubic perovskite structure. Z. Naturforsch. B 1978, 33, 862-865. [CrossRef]

58. Niu, G.; Li, W.; Li, J.; Wang, L. Progress of interface engineering in perovskite solar cells. Sci. China Mater. 2016, 59, 728-742. [CrossRef]

59. Su, J.; Chen, D.; Lin, C. Growth of large $\mathrm{CH}_{3} \mathrm{NH}_{3} \mathrm{PbX}_{3}(\mathrm{X}=\mathrm{I}, \mathrm{Br})$ single crystals in solution. J. Cryst. Growth 2015, 422, 75-79. [CrossRef]

60. Dang, Y.; Liu, Y.; Sun, Y.; Yuan, D.; Liu, X.; Lu, W.; Liu, G.; Xia, H.; Tao, X. Bulk crystal growth of hybrid perovskite material $\mathrm{CH}_{3} \mathrm{NH}_{3} \mathrm{PbI}_{3}$. CrystEngComm 2015, 17, 665-670. [CrossRef]

61. Lian, Z.; Yan, Q.; Lv, Q.; Wang, Y.; Liu, L.; Zhang, L.; Pan, S.; Li, Q.; Wang, L.; Sun, J.-L. High-performance planar-type photodetector on (100) facet of $\mathrm{MAPbI}_{3}$ single crystal. Sci. Rep. 2015, 5, 16563. [CrossRef] [PubMed]

62. Dang, Y.; Zhou, Y.; Liu, X.; Ju, D.; Xia, S.; Xia, H.; Tao, X. Formation of hybrid perovskite tin iodide single crystals by top-seeded solution growth. Angew. Chem. Int. Ed. 2016, 55, 3447-3450. [CrossRef] [PubMed]

63. Dang, Y.; Zhong, C.; Zhang, G.; Ju, D.; Wang, L.; Xia, S.; Xia, H.; Tao, X. Crystallographic investigations into properties of acentric hybrid perovskite single crystals $\mathrm{NH}\left(\mathrm{CH}_{3}\right)_{3} \mathrm{SnX}_{3}(\mathrm{X}=\mathrm{Cl}, \mathrm{Br})$. Chem. Mater. 2016, 28, 6968-6974. [CrossRef]

64. Lian, Z.; Yan, Q.; Gao, T.; Jie, D.; Lv, Q.; Ning, C.; Li, Q.; Sun, J. Perovskite $\mathrm{CH}_{3} \mathrm{NH}_{3} \mathrm{PbI}_{3}(\mathrm{Cl})$ single crystals: Rapid solution growth, unparalleled crystalline quality, and low trap density toward $108 \mathrm{~cm}^{-3}$. J. Am. Chem. Soc. 2016, 138, 9409-9412. [CrossRef] [PubMed]

65. Fang, Y.; Dong, Q.; Shao, Y.; Yuan, Y.; Huang, J. Highly narrowband perovskite single-crystal photodetectors enabled by surface-charge recombination. Nat. Photonics 2015, 9, 679-686. [CrossRef]

66. Söhnel, O.; Novotný, P.; Solc, Z. Densities of Aqueous Solutions of Inorganic Substances. J. Chem. Eng. Data 1985, 29, 379-382. [CrossRef]

67. Kadro, J.M.; Nonomura, K.; Gachet, D.; Hagfeldt, A. Facile route to freestanding $\mathrm{CH}_{3} \mathrm{NH}_{3} \mathrm{PbI}_{3}$ crystals using inverse solubility. Sci. Rep. 2015, 5, 11654. [CrossRef] [PubMed]

68. Saidaminov, M.I.; Abdelhady, A.L.; Murali, B.; Alarousu, E.; Burlakov, V.M.; Peng, W.; Dursun, I.; Wang, L.; He, Y.; Maculan, G.; et al. High-quality bulk hybrid perovskite single crystals within minutes by inverse temperature crystallization. Nat. Commun. 2015, 6, 7586. [CrossRef] [PubMed] 
69. Liu, Y.; Yang, Z.; Cui, D.; Ren, X.; Sun, J.; Liu, X.; Zhang, J.; Wei, Q.; Fan, H.; Yu, F.; et al. Two-inch-sized perovskite $\mathrm{CH}_{3} \mathrm{NH}_{3} \mathrm{PbX}_{3}(\mathrm{X}=\mathrm{Cl}, \mathrm{Br}$, I) crystals: Growthand characterization. Adv. Mater. 2015, 27, 5176-5183. [CrossRef] [PubMed]

70. Maculan, G.; Sheikh, A.D.; Abdelhady, A.L.; Saidaminov, M.I.; Haque, M.A.; Murali, B.; Alarousu, E.; Mohammed, O.F.; $\mathrm{Wu}$, T.; Bakr, O.M. $\mathrm{CH}_{3} \mathrm{NH}_{3} \mathrm{PbCl}_{3}$ single crystals: Inverse temperature crystallization and visible-blind UV-photodetector. J. Phys. Chem. Lett. 2015, 6, 3781-3786. [CrossRef] [PubMed]

71. Zhumekenov, A.A.; Saidaminov, M.I.; Haque, M.A.; Alarousu, E.; Sarmah, S.P.; Murali, B.; Dursun, I.; Miao, X.-H.; Abdelhady, A.L.; Wu, T.; et al. Formamidinium lead halide perovskite crystals with unprecedented long carrier dynamics and diffusion length. ACS Energy Lett. 2016, 1, 32-37. [CrossRef]

72. Abdelhady, A.L.; Saidaminov, M.I.; Murali, B.; Adinolfi, V.; Voznyy, O.; Katsiev, K.; Alarousu, E.; Comin, R.; Dursun, I.; Sinatra, L.; et al. Heterovalent dopant incorporation for bandgap and type engineering of perovskitecrystals. J. Phys. Chem. Lett. 2016, 7, 295-301. [CrossRef] [PubMed]

73. Han, Q.; Bae, S.H.; Sun, P.; Hsieh, Y.T.; Yang, Y.; Rim, Y.S.; Zhao, H.; Chen, Q.; Shi, W.; Li, G. Single crystal formamidinium lead iodide $\left(\mathrm{FAPbI}_{3}\right)$ : Insight into the structural, optical, and electrical properties. Adv. Mater. 2016, 28, 2253-2258. [CrossRef] [PubMed]

74. Zhang, T.; Yang, M.; Benson, E.E.; Li, Z.; Lagemaat, J.; Luther, J.M.; Yan, Y.; Zhu, K.; Zhao, Y. A facile solvothermal growth of single crystal mixed halide perovskite $\mathrm{CH}_{3} \mathrm{NH}_{3} \mathrm{~Pb}\left(\mathrm{Br}_{1-x} \mathrm{Cl}_{\mathrm{x}}\right)_{3}$. Chem. Commun. 2015, 51, 7820-7823. [CrossRef] [PubMed]

75. Saidaminov, M.I.; Abdelhady, A.L.; Maculan, G.; Bakr, O.M. Retrograde solubility of formamidinium and methylammonium lead halide perovskites enabling rapid single crystal growth. Chem. Commun. 2015, 51, 17658-17661. [CrossRef] [PubMed]

76. Yang, Y.; Yan, Y.; Yang, M.; Choi, S.; Zhu, K.; Luther, J.M.; Beard, M.C. Low surface recombination velocity in solution-grown $\mathrm{CH}_{3} \mathrm{NH}_{3} \mathrm{PbBr}_{3}$ perovskite single crystal. Nat. Commun. 2015, 6, 7961. [CrossRef] [PubMed]

77. Zhou, H.; Nie, Z.; Yin, J.; Sun, Y.; Zhou, H.; Li, D.; Dou, J.; Zhang, X.; Ma, T. Antisolvent diffusion-induced growth, equilibrium behaviours in aqueous solution and optical properties of $\mathrm{CH}_{3} \mathrm{NH}_{3} \mathrm{PbI}_{3}$ single crystals for photovoltaic applications. RSC Adv. 2015, 5, 85344-85349. [CrossRef]

78. Chen, F.; Xu, C.; Xu, Q.; Zhu, Y.; Zhu, Z.; Liu, W.; Dong, X.; Qin, F.; Shi, Z. Structure Evolution of $\mathrm{CH}_{3} \mathrm{NH}_{3} \mathrm{PbBr}_{3}$ Single Crystal Grown in $\mathrm{N}, \mathrm{N}$-Dimethylformamide Solution. Cryst. Growth Des. 2018, 18, 3132-3137. [CrossRef]

79. Li, Y.; Zhang, Y.; Zhao, Z.; Zhi, L.; Cao, X.; Jia, Y.; Lin, F.; Zhang, L.; Cui, X.; Wei, J. In Situ Investigation of the Growth of Methylammonium Lead Halide $\left(\mathrm{MAPbI}_{3-\mathrm{x}} \mathrm{Br}_{\mathrm{x}}\right)$ Perovskite from Microdroplets. Cryst. Growth Des. 2018. [CrossRef]

80. Tidhar, Y.; Edri, E.; Weissman, H.; Zohar, D.; Hodes, G.; Cahen, D.; Rybtchinski, B.; Kirmayer, S. Crystallization of methyl ammonium lead halide perovskites: Implications for photovoltaic applications. J. Am. Chem. Soc. 2014, 136, 13249-13256. [CrossRef] [PubMed]

81. Wharf, I.; Gramstad, T.; Makhija, R.; Onyszchuk, M. Synthesis and vibrational spectra of some lead(II) halide adducts with O-, S-, and N-donor atom ligand. Can. J. Chem. 1976, 54, 3430-3438. [CrossRef]

82. Peng, W.; Wang, L.; Murali, B. Solution-grown monocrystalline hybrid perovskite films for hole-transporter-free solar cells. Adv. Mater. 2016, 28, 3383-3390. [CrossRef] [PubMed]

83. Liu, Y.; Zhang, Y.; Yang, Z.; Yang, D.; Ren, X.; Pang, L.; Liu, S. Thinness and shape-controlled growth for ultrathin single-crystalline perovskite wafers for mass production of superior photoelectronic devices. Adv. Mater. 2016, 28, 9204-9209. [CrossRef] [PubMed]

84. Chen, Y.X.; Ge, Q.Q.; Shi, Y.; Liu, J.; Xue, D.; Ma, J.; Ding, J.; Yan, H.; Hu, J.; Wan, L. General space-confined on-substrate fabrication of thickness-adjustable hybrid perovskite single-crystalline thin films. J. Am. Chem. Soc. 2016, 138, 16196-16199. [CrossRef] [PubMed]

85. Rao, H.S.; Li, W.G.; Chen, B.X.; Kuang, D.; Su, C. In situ growth of $120 \mathrm{~cm}^{2} \mathrm{CH}_{3} \mathrm{NH}_{3} \mathrm{PbBr}_{3}$ perovskite crystal film on FTO glass for narrow band-photodetectors. Adv. Mater. 2017, 29, 1602639. [CrossRef] [PubMed]

86. Schmidt, L.C.; Pertegás, A.; González-Carrero, S.; Malinkiewicz, O.; Agouram, S.; Mínguez Espallargas, G.; Bolink, H.J.; Galian, R.E.; Pérez-Prieto, J. Nontemplate Synthesis of $\mathrm{CH}_{3} \mathrm{NH}_{3} \mathrm{PbBr}_{3}$ Perovskite Nanoparticles. J. Am. Chem. Soc. 2014, 136, 850-853. [CrossRef] [PubMed]

87. Tong, Y.; Ehrat, F.; Vanderlinden, W.; Cardenasdaw, C.; Stolarczyk, J.K.; Polavarapu, L.; Urban, A.S. Dilution-Induced Formation of Hybrid Perovskite Nanoplatelets. ACS Nano 2016, 10, 10936-10944. [CrossRef] [PubMed] 
88. Imran, M.; Caligiuri, V.; Wang, M.; Goldoni, L.; Prato, M.; Krahne, R.; De Trizio, L.; Manna, L. Benzoyl Halides as Alternative Precursors for the Colloidal Synthesis of Lead-Based Halide Perovskite Nanocrystals. J. Am. Chem. Soc. 2018, 140, 2656-2664. [CrossRef] [PubMed]

89. Protesescu, L.; Yakunin, S.; Kumar, S.; Bär, J.; Bertolotti, F.; Masciocchi, N.; Guagliardi, A.; Grotevent, M.; Shorubalko, I.; Bodnarchuk, M.I.; et al. Dismantling the "Red Wall" of Colloidal Perovskites: Highly Luminescent Formamidinium and Formamidinium-Cesium Lead Iodide Nanocrystals. ACS Nano 2017, 11, 3119-3134. [CrossRef] [PubMed]

90. Bi, D.; Tress, W.; Dar, M.I.; Gao, P.; Luo, J.; Renevier, C.; Schenk, K.; Abate, A.; Giordano, F.; Baena, J.P.C.; et al. Efficient luminescent solar cells based on tailored mixed-cation perovskites. Sci. Adv. 2016, 2, 1501170. [CrossRef] [PubMed]

91. Jacobsson, T.J.; Correa-Baena, J.; Pazoki, M.; Saliba, M.; Schenk, K.; Gratzel, M.; Hagfeldt, A. Exploration of the compositional space for mixed lead halogen perovskites for high efficiency solar cells. Energy Environ. Sci. 2016, 9, 1706-1724. [CrossRef]

92. Li, W.G.; Rao, H.S.; Chen, B.X.; Wang, X.D.; Kuang, D.B. A formamidinium-methylammonium lead iodide perovskite single crystal exhibiting exceptional optoelectronic properties and long-term stability. J. Mater. Chem. A 2017, 5, 19431-19438. [CrossRef]

93. Huang, Y.; Li, L.; Liu, Z.; Jiao, H.; Jiao, H.Y.; Wang, X.; Zhu, R.; Wang, D.; Sun, J.; Chen, Q.; et al. The Intrinsic Properties of FA $(1-x) \mathrm{MA}_{x} \mathrm{PbI}_{3}$ Perovskite Single Crystals. J. Mater. Chem. A 2017, 5, 8537-8544. [CrossRef]

94. Xie, L.Q.; Chen, L.; Nan, Z.A.; Lin, H.X.; Wang, T.; Zhan, D.P. Understanding the cubic phase stabilization and crystallization kinetics in mixed cations and halides perovskite single crystals. J. Am. Chem. Soc. 2017, 139, 3320-3323. [CrossRef] [PubMed]

95. Kulbak, M.; Cahen, D.; Hodes, G. How Important Is the Organic Part of Lead Halide Perovskite Photovoltaic Cells? Efficient $\mathrm{CsPbBr}_{3}$ Cells. J. Phys. Chem. Lett. 2015, 6, 2452-2456. [CrossRef] [PubMed]

96. Protesescu, L.; Yakunin, S.; Bodnarchuk, M.I.; Krieg, F.; Caputo, R.; Hendon, C.H.; Yang, R.X.; Walsh, A.; Kovalenko, M.V. Nanocrystals of Cesium Lead Halide Perovskites ( $\mathrm{CsPbX}_{3}, \mathrm{X}=\mathrm{Cl}, \mathrm{Br}$, and I): Novel Optoelectronic Materials Showing Bright Emission with Wide Color Gamut. Nano Lett. 2015, 15, 3692-3696. [CrossRef] [PubMed]

97. Stoumpos, C.C.; Malliakas, C.D.; Peters, J.A.; Liu, Z.; Sebastian, M.; Im, J.; Chasapis, T.C.; Wibowo, A.C.; Chung, D.Y.; Freeman, A.J. Crystal Growth of the Perovskite Semiconductor $\mathrm{CsPbBr}_{3}$ : A New Material for High-Energy Radiation Detection. Cryst. Growth Des. 2013, 13, 2722-2727. [CrossRef]

98. Kobayashi, M.; Omata, K.; Sugimoto, S.; Tamagawa, Y.; Kuroiwa, T.; Asada, H.; Takeuchi, H.; Kondo, S. Scintillation Characteristics of $\mathrm{CsPbCl}_{3}$ Single Crystals. Nucl. Instrum. Methods Phys. Res. Sect. A 2008, 592, 369-373.

99. Clark, D.J.; Stoumpos, C.C.; Saouma, F.O.; Kanatzidis, M.G.; Jang, J.I. Polarization-Selective Three-Photon Absorption and Subsequent Photoluminescence in $\mathrm{CsPbBr}_{3}$ Single Crystal at Room Temperature. Phys. Rev. B 2016, 93, 195202. [CrossRef]

100. Nitsch, K.; Hamplová, V.; Nikl, M.; Polák, K.; Rodová, M. Lead Bromide and Ternary Alkali Lead Bromide Single Crystals-Growth and Emission Properties. Chem. Phys. Lett. 1996, 258, 518-522. [CrossRef]

101. Dirin, D.N.; Cherniukh, I.; Yakunin, S.; Shynkarenko, Y.; Kovalenko, M.V. Solution-Grown $\mathrm{CsPbBr}_{3}$ Perovskite Single Crystals for Photon Detection. Chem. Mater. 2016, 28, 8470-8474. [CrossRef] [PubMed]

102. Rakita, Y.; Kedem, N.; Gupta, S.; Sadhanala, A.; Kalchenko, V.; Bohm, M.L.; Kulbak, M.; Friend, R.H.; Cahen, D.; Hodes, G. Low-temperature solution-grown $\mathrm{CsPbBr}_{3}$ single crystals and their characterization. Cryst. Growth Des. 2016, 16, 5717-5725. [CrossRef]

103. Tong, Y.; Bladt, E.; Ayguler, M.F.; Manzi, A.; Milowska, K.Z.; Hintermayr, V.A.; Hintermayr, P.D.; Sara, B.; Alexander, S.U.; Lakshminarayana, P.; et al. Highly Luminescent Cesium Lead Halide Perovskite Nanocrystals with Tunable Composition and Thickness by Ultrasonication. Angew. Chem. Int. Ed. 2016, 55, 13887-13892. [CrossRef] [PubMed]

104. Tong, Y.; Bohn, B.J.; Bladt, E.; Wang, K.; Peter, M.-B.; Bals, S.; Urban, A.S.; Polavarapu, L.; Feldmann, J. Feldmann From Precursor Powders to $\mathrm{CsPbX}_{3}$ Perovskite Nanowires: One-Pot Synthesis, Growth Mechanism, and Oriented Self-Assembly. Angew. Chem. Int. Ed. 2017, 56, 13887-13892. [CrossRef] [PubMed]

105. Slavney, A.H.; Hu, T.; Lindenberg, A.M.; Karunadasa, H.I. A Bismuth-Halide Double Perovskite with Long Carrier Recombination Lifetime for Photovoltaic Applications. J. Am. Chem. Soc. 2016, 138, 2138-2141. [CrossRef] [PubMed] 
106. Dong, Q.; Song, J.; Fang, Y.; Shao, Y.; Ducharme, S.; Huang, J. Lateral-structure single-crystal hybrid perovskite solar cells via piezoelectric poling. Adv. Mater. 2016, 28, 2816-2821. [CrossRef] [PubMed]

107. Monroy, E.; Omnès, F.; Calle, F. Topical review: Wide-band gap semiconductor ultraviolet photodetectors. Semicond. Sci. Technol. 2003, 18, R33-R51. [CrossRef]

108. Ghezzi, D.; Antognazza, M.R.; Dal, M.M.; Lanzarini, E.; Benfenati, F.; Lanzani, G. A hybrid bioorganic interface for neuronal photoactivation. Nat. Commun. 2011, 2, 166. [CrossRef] [PubMed]

109. Razeghi, M.; Rogalski, A.J. Semiconductor ultraviolet detectors. J. Appl. Phys. 1996, 79, 7433-7473. [CrossRef]

110. Manga, K.K.; Wang, J.; Lin, M.; Zhang, J.; Nesladek, M.; Nalla, V.; Ji, W.; Loh, K.P. High-Performance Broadband Photodetector Using Solution-Processible PbSe-TiO $2-G r a p h e n e$ Hybrids. Adv. Mater. 2012, 24, 1697-1702. [CrossRef] [PubMed]

111. Li, S.; Tong, S.; Meng, J.; Zhang, C.; Zhang, C.; Shen, J.; Xiao, S.; Sun, J.; He, J.; Gao, Y.; et al. Fast-response and high-responsivity $\mathrm{FA}_{\mathrm{x}} \mathrm{MA}_{(1-\mathrm{x})} \mathrm{Pbl}_{3}$ photodetectors fabricated via doctor-blading deposition in ambient condition. Org. Electron. 2018, 52, 190-194. [CrossRef]

112. Tong, S.; Wu, H.; Zhang, C.; Li, S.; Wang, C.; Shen, J.; Xiao, S.; He, J.; Yang, J.; Sun, J.; et al. Large-area and high-performance $\mathrm{CH}_{3} \mathrm{NH}_{3} \mathrm{PbI}_{3}$ perovskite photodetectors fabricated via doctor blading in ambient condition. Org. Electron. 2017, 49, 347-354. [CrossRef]

113. Tong, S.; Sun, J.; Wang, C.; Huang, Y.; Zhang, C.; Shen, J.; Xie, H.; Niu, D.; Xiao, S.; Yuan, Y.; et al. High-Performance Broad band Perovskite Photodetectors Based on $\mathrm{CH}_{3} \mathrm{NH}_{3} \mathrm{PbI}_{3} / \mathrm{C} 8 \mathrm{BTBT}$ Heterojunction. Adv. Electron. Mater. 2017, 3, 1700058. [CrossRef]

114. Ding, J.; Fang, H.; Lian, Z.; Li, J.; Lv, Q.; Wang, L.; Sun, J.; Yan, Q. A self-powered photodetector based on a $\mathrm{CH}_{3} \mathrm{NH}_{3} \mathrm{PbI}_{3}$ single crystal with asymmetric electrodes. CrystEngComm 2016, 18, 4405-4411. [CrossRef]

115. Shaikh, P.; Shi, D.; Retamal, J.; Sheikh, A.D.; Haque, M.A. Schottky junctions on perovskite single crystals: Light-modulated dielectric constant and self-biased photodetection. J. Mater. Chem. C 2016, 4, 8304-8312. [CrossRef]

116. Cao, M.; Tian, J.; Cai, Z.; Peng, L.; Yang, L.; Wei, D. Perovskite heterojunction based on $\mathrm{CH}_{3} \mathrm{NH}_{3} \mathrm{PbBr}_{3}$ single crystal for high-sensitive self-powered photodetector. Appl. Phys. Lett. 2016, 109, 233303. [CrossRef]

117. Yakunin, S.; Sytnyk, M.; Kriegner, D.; Shrestha, S.; Richter, M.; Matt, G.J.; Azimi, H.; Brabec, C.J.; Stangl, J.; Kovalenko, M.V.; et al. Detection of X-ray photons by solution-processed lead halide perovskites. Nat. Photonics 2015, 9, 444-449. [CrossRef] [PubMed]

118. Wei, H.; Fang, Y.; Mulligan, P.; Chuirazzi, W.; Fang, H.-H.; Wang, C.; Ecker, B.R.; Gao, Y.; Loi, M.A.; Cao, L.; et al. Sensitive X-ray detectors made of Methylammonium lead tribromide perovskite single crystals. Nat. Photonics 2016, 10, 333-339. [CrossRef]

(C) 2018 by the authors. Licensee MDPI, Basel, Switzerland. This article is an open access article distributed under the terms and conditions of the Creative Commons Attribution (CC BY) license (http:/ / creativecommons.org/licenses/by/4.0/). 